\title{
Drought in the forest breaks plant-fungi interactions
}

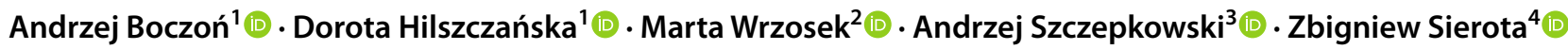

Received: 18 January 2021 / Revised: 9 August 2021 / Accepted: 12 August 2021 / Published online: 4 September 2021

(c) The Author(s) 2021

\begin{abstract}
Drought in the forest is not only a prolonged state of water shortage, but also an occasion where interactions between plants and fungi are affected. Water efficiency accelerates a range of pathologies in interactions between organisms, influencing the ecosystems and their interacting biological components. This study focuses on the role of mycorrhizal and endophyte fungi in alleviating the effects of soil water shortage, and on the impact of their altered activity during drought on the health of trees. The issues presented here show the fundamental role of the mycorrhizal mycelium and the mechanism of water transport to the plant in the course of other phenomena (withering, pathogenesis, endophytes biology) that occur in trees under influence of drought, with particular attention on managed coniferous stands. Conclusions resulting from published information on this topic emphasize the negative impact of soil moisture deficiency on the ectomycorrhizal fungi functioning and, in contrast, on the promotion of the growth of some endophytes, pathogens and hemi-parasitic mistletoes (Viscum spp.).
\end{abstract}

Keywords Water deficit $\cdot$ Nutrients $\cdot$ Mycorrhiza $\cdot$ Endophytes $\cdot$ Transpiration $\cdot$ Tree vitality $\cdot$ Pathogens $\cdot$ Forest dieback

\section{Introduction}

Maintaining forests in good health under conditions of global climate change is one of the most critical challenges faced by foresters. Although rainfall intensity and frequency increased in the Northern Hemisphere in the second half

Communicated by Oliver Gailing.

https://www.researchgate.net/publication/265935320_Examining_ the_spatio-temporal_evolution_and_characteristics_of_largescale_European_droughts.

Dorota Hilszczańska

d.hilszczanska@ibles.waw.pl

1 Department of Forest Ecology, The Forest Research Institute, Sękocin Stary, Braci Leśnej 3, 05-090 Raszyn, Poland

2 Faculty of Biology, Biological and Chemical Research Centre, Botanic Garden, University of Warsaw, Al. Ujazdowskie 4, 00-478 Warsaw, Poland

3 Department of Forest Protection, Institute of Forest Sciences, The Warsaw University of Life Sciences - SGGW, Nowoursynowska 159, 02-776 Warszawa, Poland

4 Department of Forestry and Forest Ecology, Faculty of Environmental Management and Agriculture, The University of Warmia and Mazury in Olsztyn, Pl. Łódzki 2, 10-727 Olsztyn, Poland of the twentieth century, many areas were also affected by drought (Stocker et al. 2013). Drought is increasingly observed in connection with the global water crisis resulting from climate change, while it is also attributable to human activities, e.g., because of influence on ground water, deforestation, and inappropriate land drainage (Lenton and Muller 2012). The massive devastating wildfires in many regions of the world are the most alarming example of drought caused by climate change. This dangerous phenomenon is also observed in Central and Northern Europe (Škvarenina and Vida 2009; CTIF 2019; Krikken et al. 2019; Venäläinen et al. 2020). In Poland as example, the area of forests seriously affected by drought has been increasing and, in 2018, was estimated to have affected 43.5 thousand hectares of forest (Zajączkowski et al. 2019).

Coniferous forests occupying the Central European lowlands, however, adapted to local growing conditions, they are nevertheless vulnerable to harmful effects of climate change (Vitali et al. 2018). Most of these forests, especially stands with domination of Pinus sylvestris, grow on poor sandy soils with low water retention capacity, which increases the risk of drought as the climate is becoming warmer. These stands receiving relatively low rainfall, react the fastest to the lack of water in the soil, to low precipitation, and longlasting insolation. 
The increased risk of drought on forests, which is associated with global climate change, is indicated by the average annual rainfall of $<600 \mathrm{~mm}$ and noted in 313-316 sub-provinces of Germany and Poland (Banaszkiewicz et al. 2008; Panka 2012; Solon et al. 2018) and in other countries in Europe, as well (Caloiero et al. 2018). Forests in the European regions influenced by both maritime and continental climates, are more susceptible to altered weather conditions. Planting tree species that have greater resistance to high temperatures and drought may, however, result in severe frost damage, since below freezing temperatures may occur in the European lowlands even in late May (Körner et al. 2016; Agafonova et al. 2017). Given that trees have life spans of more than 100 years, the risk of high losses due to reduced soil moisture and adverse weather conditions over the coming century is substantial (Lindner et al. 2010). In addition, some tree species, especially conifers, were used in largescale afforestation-in Poland and East Germany on postagricultural soils or in Ukraine in the steppe zone. In such habitats the trees still are not fully productive or resistant (Soloviy 2000; Wegehenkel 2003; Sierota 2013).

To present the overall complexity of the impact of drought on tree mortality, it is necessary to clearly explain the course of this process, which occurs simultaneously in the roots, trunk, and the crown of the tree (Davi and Cailleret 2017). Considering the genetically and epigenetically encoded regulation of trees' resistance, to better understand forest drought, we should pay special attention to the soil microcosm which is connected to the uptake of water by the roots and, indirectly also its transpiration in the crowns of trees (Hagedorn et al. 2016). The xylem water conduction has well known physical nature but is strongly influenced by the surface and activity of mycorrhizal mycelium in the soil and the presence of some fungi in the vessels and coils of inhabited wood (Abdullah et al. 2017), which in turn may contribute to disrupting the water flow up the tree. Figure 1 abstracts the fungal role in this process in the drought condition.

The present work reviews the state of knowledge on changes occurring in the trees during drought in coniferous stands in central Europe. Emphasis is paid to the different role of mycorrhizal fungi, as well as endophytes and pathogens in trees under stress condition. These dependencies are not sufficiently known to both forestry practitioners and forest managers. Research is rare that simultaneously observes the tree crown and the root system.

To review the analysis of drought impact on forests in Central Europe and its relations to fungi, the databases in Scopus, Google Scholar and Web of Science were browsed. Broad literature focusing on response of specific fungi to the drought and climate change was found-more than 607 thousand articles for mycorrhiza, however records of works focusing on drought-stressed plants in the context of cooccurring fungi (mycorrhizal, endophytic, and pathogenic ones) were much rarer. The objectives were focused on general information about the role of mycorrhiza and fungi inhabiting drought-stressed trees with special references to water uptake. We also tried to identify gaps in research and possible future methods of trees' protection against drought.

\section{Drought in Central Europe in the last decade and climate change forecast}

The average global air temperature in 1880-2012 increased by $0.85^{\circ} \mathrm{C}$, and the first decade of the twenty-first century is the warmest since instrumental measurements began (IPCC 2013). One of the effects of global warming is the increased intensity, duration, and area of drought since 1970. On a global scale an increase in the percentage of annual drought
Fig. 1 Diagram showing the order of changes in the health condition of trees in drought conditions (drawing: M. Wrzosek)

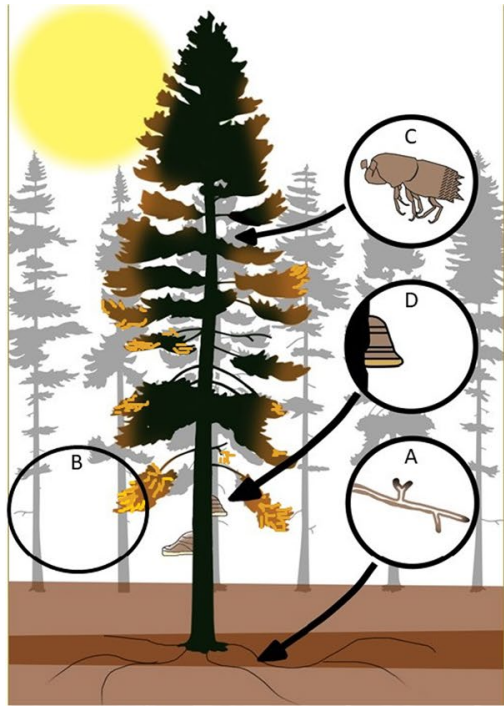


periods experiencing many different areas from 1902-2008 has been observed (Wang et al. 2014). Particularly acute was a drought in Europe in summer 2003, when heat was extremely high (Burke et al. 2006; Rebetez et al. 2006; Blunden et al. 2011). In central Europe, it is anticipated that climate change will result in warmer temperature and lower rainfall during the growing season (Briffa et al. 2009; Dubrovský et al. 2009). The Soil Moisture Anomaly (SMA), an indicator of agricultural drought conditions compiled by the JRC European Drought Observatory (EDO), shows that droughts beginning in spring of 2015 and 2018 affected Germany, Greece, western Poland, and Scandinavia (Masante and Vogt 2018; Masante et al. 2018; Spinoni et al. 2018). In September 2018, drought had been relieved in Scandinavia, but had appeared west to cover France, remaining also in Poland (Masante et al. 2019). Drought Severity Index (DSI) for 10-day periods from April to July 2015 shows a gradual increase from mid-May in many parts of Europe. In May 2015, the drought covered Germany and western Poland, after which drought spread in all directions and increased its severity, covering almost all of Europe, except Scandinavia. In 2018, Central Europe experienced one of the most severe and long-lasting summer drought and heat wave ever recorded. Before 2018, the 2003 millennial drought was often invoked as the example of a "hotter drought" and was classified as the most severe event in Europe for the last 500 years (Schuldt et al. 2020). First insights now confirm that the 2018 drought event was climatically more extreme and had a greater impact on forest ecosystems of Austria, Germany, and Switzerland than the 2003 drought (Schuldt et al. 2020). According to monitoring by JRC EDO, drought occurred in Europe again in 2019. They determined that several regions spanning from northeast to western Europe experienced drought conditions, including Lithuania, central Poland, Czech Republic, Germany, central France, and central Spain (Masante et al. 2019). Droughts in Poland were described in detail by Zajączkowski et al. (2019), based on a modified climate water balance indicator and the number of days with limited soil water availability. In the periods assessed, the best moisture conditions for the growth of forest stands occurred in Poland in 2010, 2013, 2017, while the longest droughts, covering large parts of the country, occurred in 2015 and 2018 (Fig. 2). In 2015 a large moisture deficit covered almost the entire country (Boczoń et al. 2016). The climatic water balance of the warm half-year showed a moisture deficit exceeding $200 \mathrm{~mm}$. A moisture shortage in the summer months in 2015 covered $87 \%$ of Poland. Based on the annual climate water balance of forested areas, moisture deficits (mean $140 \mathrm{~mm}$, up to $300 \mathrm{~mm}$ ) occurred in 2018 in both western and southeastern Poland. A more detailed analysis shows the increasing risk of drought also in the east, as well as in the central part of the Baltic coastal areas (Boczoń, unpublished).

According to the InterSucho project, which maps the occurrence of drought in the Czech Republic, in July 2019, $63 \%$ of the country was seriously affected (Fraňková 2019; InterSucho 2019). Climatic anomalies causing drought are a great threat to forest ecosystems: in the warm half of the year, soil water decreased because evapotranspirational losses generally exceed precipitation and leads to faster soil water depletion. European Environment Agency publishes the current drought prognosis for the continent up to 2100 and states that the frequency and severity of droughts will be increased in most parts of Europe. The maps illustrating the problem are shown on the webpage: https://www.eea. europa.eu/data-and-maps/indicators/river-flow-drought-3/ assessment.

\section{Responses of host-plants and mycorrhizal fungi under drought conditions}

Mycorrhiza is a mutualistic symbiosis between a plant's roots and a specific fungus, which plays an integral role in the root-soil interface, influencing nutrient cycling and shaping terrestrial ecosystems. Mycorrhizal fungi are widely
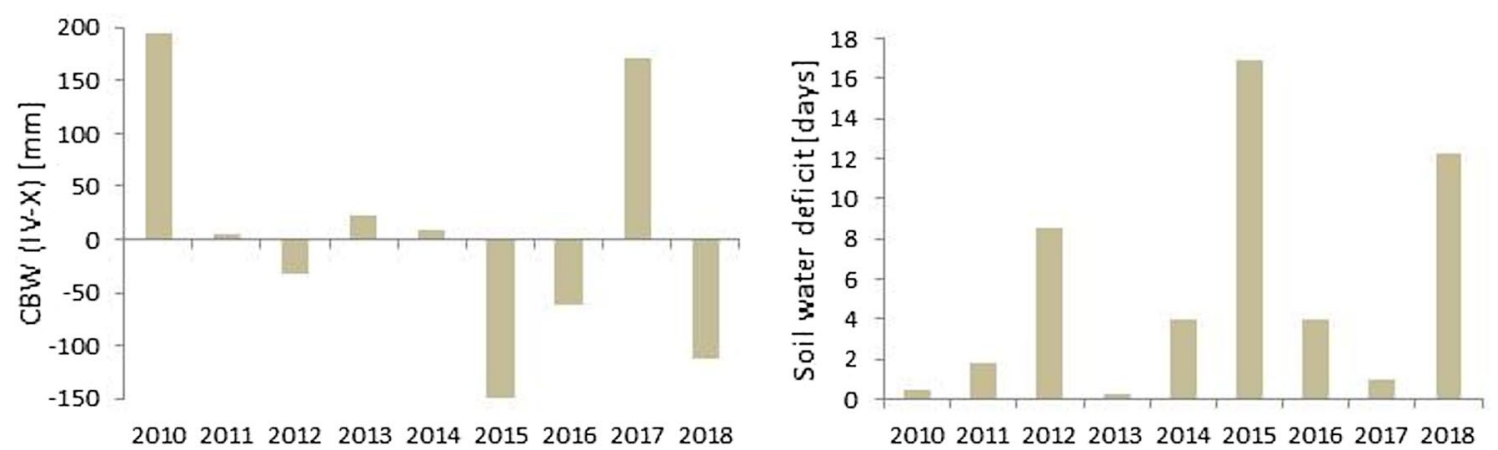

Fig. 2 Average drought indices weighted by the area affected in Poland, left—climatic water balance (CWB) for April-September, right-number of days with soil water deficit from May to July (A. Boczoń, unpublished data) 
distributed in different types of terrestrial ecosystems and include several groups, forming, respectively, to own properties different types of fungus-plant interactions, known as ectomycorrhiza (EM), arbuscular mycorrhiza (AM), ericoid, orchid mycorrhiza, and others. Fungal-plant symbiosis is often context-dependent and differentially responds to the water depletion's stress. Mycorrhizal associations are formed by plants and fungi from different taxonomic groups, but only ectomycorriza (EM) occurring between woody plants and asco- and basiodiomycetous fungi produces pronounced mantle, Hartig net and large extramatrical mycelium (Schubert et al. 1987; Song et al. 2007; Smith and Read 2008). The initial stage of mycorrhiza formation includes a signal exchange between the two symbionts, physical connection, and functional integration (Kowalczyk and Hrynkiewicz 2018). In EM symbiosis (Blasius et al. 1986; Taylor and Alexander 2005), this integration consists of: (1) the Hartig net, responsible for the direct transfer of water and minerals into plant cells, in exchange the fungus receives carbohydrates and other compounds necessary for mycelium growth, (2) a hyphal mantle around the root, providing structural protection, increasing the absorbing surface and storing moisture, (3) a hyphal network of extrametrical mycelium, penetrating the soil at a speed of up to $4 \mathrm{~mm} /$ day (Fig. 3). This type of mycorrhiza is usually strongly affected by drought but at the same time its state could be crucial for tree resistance to drought. In AM symbiosis, fungi form a specific appressorium called hyphopodium which penetrates the root through the pre-penetration apparatus, which guides the fungal hyphae through the root cells toward the bark (Parniske 2008; Krishnakumar et al. 2013). In the cortex, the hyphae enter the apoplast and grow laterally along the root axis,

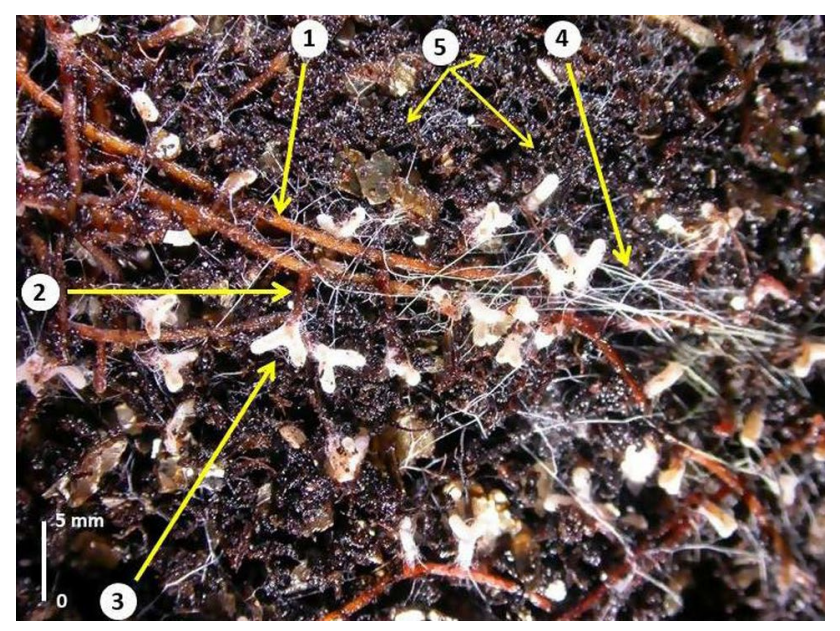

Fig. 3 Scots pine roots with Scleroderma citrinum mycorrhizae in soil. 1-n-order roots, 2-lateral $\mathrm{n}+1$ roots, 3-dichotomous mycorrhizal roots with mantle, 4-ectomycorrhizal extrametrical mycelium, 5individual hyphae, visible as white spots that are reflections of light (Photo: D. Hilszczańska) occupying inner root cortical cells. The intracellular hyphae form structures by repeated branching known as arbuscules that are considered as the site of nutrient exchange. While arbuscular mycorrhizas are the most common form of mycorrhizal interactions occurring in the roots of approx. $65-90 \%$ of all land plant species including flowering plants, bryophytes, and ferns (Zhu et al. 2010), the mechanisms controlling arbuscule development are still largely unknown (Paszkowski 2006). The AM mycorrhiza is less influenced by drought. A normally developed root system of temperate tree species usually forms symbiotic associations with EM fungi (Bonfante and Genre 2010; Cosme et al. 2018), but arbuscular mycorrhizae are also important because they can interact with them. The two types of mycorrhizae (AM and EM) can coexist with one plant species including Populus spp and Pinus spp improving the state of plants under drought conditions (Teste et al. 2020, Karlst et al. 2021).

\section{Mycorrhizae and water uptake}

Mycorrhizal symbiosis plays a major role in two plant processes: water-mineral absorption and the allocation of carbon within the plant, with some carbon compounds ultimately transferred to ectomycorrhizal fungi (Guehl and Garbaye 1990; Simard 2003; Courty et al. 2010). Ectomycorrhizal plants often have higher nutrient contents than non-mycorrhizal plants, especially when grown in soils with low nutrient availability. This is the typical condition of pine stands located on poor sandy soils in many European countries, where the ectomycorrhizal net also substantially improves the uptake of water by trees (Jones et al. 1990). Roots with associated extrametrical mycelium can explore a larger volume of soil than non-mycorrhizal roots, and hyphae can explore small soil pores that are not accessible to plant roots (Garbaye 2000; Lheto and Zwiazek 2011), thus improving plant water status under low soil moisture conditions (Morte et al. 2001; Duñabeitia et al. 2004). However, some authors have failed to find a beneficial effect of ectomycorrhizal fungi in dry conditions, suggesting that both plant and fungus can be directly limited by water availability (Dosskey et al. 1991; Kennedy and Peay 2007; Peay et al. 2015). Drought may reduce fungal growth and limit its ability to supply the plant with nutrients. Simultaneously, the plant responds to drought by limiting carbon flow to the roots, suppressing the fungal symbiont. It has been experimentally shown that plant response to drought varies considerably depending on the associated fungal species (Lamhamedi et al. 1992). Recent data suggest that fungal transmembrane water channels, i.e., aquaporins, regulate the acquisition and release of water by the hyphae, and therefore could induce drought tolerance (Xu and Zwiazek 2020). Ectomycorrhizal fungi have different capabilities for transporting water. Barnes et al. (2018) suggest that some 
fungi do not respond favorably to saturated soil moisture conditions, regardless of their role in its transport. The ability to colonize a host root is also greatly affected by water supply. In microcosms of Scots pine (Pinus sylvestris), the colonization abilities of three ectomycorrhizal species, viz., Thelephora terrestris, Laccaria laccata and Hebeloma crustuliniforme, were insensitive to flooding, whereas Suillus flavidus and S. bovinus were sensitive (Stenström 1991). Plamboeck et al. (2007) found species-specific effects of ectomycorrhizal fungi on hyphal transport of water. In the test performed with isotope and fluorescent dye analysis, only one of 15 ectomycorrhizal fungal morphotypes was able to transfer stained water to Douglas-fir seedlings. In work by Prieto et al. (2016), T. terrestris hyphae enhanced interplant transfer and redistribution of water between Pinus halepensis saplings and seedlings whereas Suillus granulatus did not.

Arbuscular mycorrhizal fungi (AM) are able to strengthen the growth of host plants especially under stressful conditions by mediating a series of complex communication processes between the plant and the fungus leading to increased photosynthetic rate and other gas exchange-related traits (Birhane et al. 2012). Plant tolerance to drought could be primarily due to a large volume of soil explored by roots and the extra-radical hyphae of the fungi (Gutjahr and Paszkowski 2013). There is an extensive literature on plant responses to AM inoculation on host species exposed to drought. For example, Glycine max L. growing in water stress conditions after inoculation with AM enhanced leaf proline, photosynthesis, leaf area index, relative growth rate, fresh weight, and dry weight of seeds (Pavithra and Yapa 2018). Ouledali et al. (2018) showed that AM alleviated drought impact and increased turgor potential $(\Psi \mathrm{p})$ and mineral uptake of olive trees (Olea europaea L.). Increased dry biomass, water usage effectiveness and net photosynthetic rate of Robinia pseudoacacia L. seedlings inoculated with AM fungi (Funneliformis mosseae and Rhizophagus intraradices) have been observed (Yang et al. 2014). Numerous evidences of improved resistance also to salinity, herbivory, temperature, heavy metals pollution, and diseases due to fungal symbiosis have been reported (Rodriguez et al. 2008; Salam et al. 2017).

It is worthy to notice the results obtained by Morgado et al. $(2015,2016)$. The authors show the possible shift in composition of mycorrhizal fungi in Arctic ecosystems with different depths of snow cover and different temperatures. A relevant adaptation of ectomycorrhizal fungi is the degree of hydrophobicity of their below-ground structures, and the plasticity of this property in response to environmental conditions. Some species of fungi produce hydrophobic rhizomorphs that facilitate transport of soluble substrates and water (Unestam and Sun 1995), and hydrophobicity is likely to be a trait that provides stress tolerance for soil-borne fungi. These remarks should be a guideline in searching for more resistant mycorrhizal fungi.

Depending on fungal species, ectomycorrhizal fungi differ in the anatomy and morphology of the mycelia radiating into the soil, and these morphological variations are believed to be related to ecological functions and modes of foraging exploration (Agerer 2001; Shahin et al. 2013). It has been suggested that ectomycorrhizal root tips with hydrophobic mantles and highly differentiated extensive external mycelium (i.e., so-called rhizomorphs, developed by Boletus and Cortinarius genera), are resistant to drought and effective at water transport and uptake for their hosts (de Jalon et al. 2020). Some species of the genus Cortinarius are specially adapted to dry conditions, probably due to the characteristics of their mycelium, which are hydrophobic and much more persistent than mycelium of other mycorrhizal fungi, for example those belonging to the genus Tomentella. Moreover, Cortinarius spp. excrete Mn-dependent peroxidases, which participate in enzymatic oxidation of humus to release nutrients from dead organic matter in northern forest ecosystems. The abundance of Cortinarius spp. is likely to increase with climate change, including in northern hemisphere forests (Bödeker et al. 2014).

Gehring et al. (2017) found that ectomycorrhizal community composition is under strong plant genetic control. Inoculation experiments have shown that ectomycorrhizal communities are critical to plant drought tolerance. Both drought-tolerant and drought-intolerant seedlings grew similarly when provided sterile ectomycorrhizal inoculum. However, drought-tolerant seedlings grew 25\% larger than the drought-intolerant seedlings under dry conditions. Each seedling type developed its distinct ectomycorrhizal community. This outcome demonstrates that combinations of plant genotype and ectomycorrhizal communities improve the survival and growth of trees under drought, which is of great importance due to the vulnerability of forests around the world to the warmer and drier climates predicted for the future (Pilosof et al. 2017). Since the fungal EM network connecting plants stabilizes the ecosystem, as shown by Simard (2009), the composition of drought-tolerant trees and drought-tolerant fungi, especially those that can connect with different partners, may be a crucial issue in future forest design.

\section{Mycorrhizae and nutrients uptake}

Functional variation exists among taxa of ectomycorrhizal fungi in the ability to utilize different nutrient sources to obtain nitrogen (Abuzinadah and Read 1989; Jones et al. 2009) and phosphorus (Colpaert et al. 1999). Fungal species can be characterized in terms of their capabilities for nutrient acquisition under given environmental conditions, based on the specific extracellular enzymes involved in degradation of 
celluloses, hemicelluloses, chitin and proteins, the oxidation of phenols and the mobilization of phosphorus (Courty et al. 2005; Pritsch and Garbaye 2011).

According to Harley (1989), mycelium use $30 \%$ of the carbon assimilated in the process of photosynthesis by the plant. Van der Heijden et al. (2015) stated that up to $80 \%$ of nitrogen and up to $90 \%$ of phosphorus requirements of plants are acquired by mycelium. The presence of ectomycorrhizal mycelium (including emanating elements) is strongly correlated with higher phosphorus levels in young trees (Rousseau et al. 1992). Feedback between mycorrhiza and a tree affects the state of the crown and the condition of its roots, including mycorrhizal tips and extramatrical mycelium (Fig. 4). Phosphorus is assimilated by both types of mycorrhizae by solubilization of inorganic phosphorus and hydrolysis of organic phosphorus from soil (George et al. 1995; Hilszczańska et al. 2008; Hilszczańska 2009). Its uptake by trees is improved effectively by AM fungi. It should be an appropriate practice to plant some species that exhibit two types of mycorrhizae (EM+AM) or to encourage the growth of herbaceous plants in forests that can associate with EM mycelium. Fern Pteridium aquilinum is often seen as a kind of weed in forests (Milligan et al. 2016), with strong competitive properties but also is a plant that connects with trees through the mycorrhizal network (Conway and Arbuthnott 1949; Acsai and Largent 1983; Ouden 2000). The negative impact of Pteridium on herbaceous plants can be balanced by the improvement of trees' roots state. The effectiveness of mycorrhiza in promoting the growth and nutrition of trees depends on an association with a suitable ectomycorrhizal fungal species, even down to strain. Along with the abundance of ectomycorrhizae, the amount and degree of differentiation of extramatrical mycelium is an important ecological factor underpinning tree performance (Colpaert et al. 1992; Thomson et al. 1994). The negative effect of drought on potassium uptake was shown in several studies (Agerer 2001; Smith and Read 2008; Van der Linde et al. 2018). It was found that ectomycorrhizal fungi with hydrophobic mycelium transfer more potassium ions than those that have hydrophilic mycelium. Danielsen and Polle (2014) revealed that young poplar (Populus $\times$ canescens) growing under dry conditions had higher levels of phosphorus and other cations, in particular potassium, in shoots of ectomycorrhizal plants, but not in roots. Similarly, $\mathrm{Mg}$ increased in roots regardless of ectomycorrhizal status, whereas foliar concentrations of $\mathrm{Mg}$ increased only in ectomycorrhizal plants (Danielsen and Polle 2014). The activity of both EM and AM fungi aids in preventing salt-induced ion toxicity while alleviating nutrient deficiency (Kapoor et al. 2013).

It is also known that higher $\mathrm{CO}_{2}$ levels in laboratory conditions change the composition and influence of the microbial community in soil. AM fungi, e.g., of the Gigasporaceae family, have positive effects on plants under conditions of elevated $\mathrm{CO}_{2}$, whereas elevated $\mathrm{CO}_{2}$ has strong negative effects on Glomaceae fungi. $\mathrm{A} \mathrm{CO}_{2}$ - enriched atmosphere, which causes the greenhouse effect, can reduce the benefits of mycorrhizae, negatively affecting plant functionality (Johnson et al. 2005).

The functioning of mycorrhizal systems and their role as donors of mineral compounds to trees is often discussed in the context of the impact of nitrogen on tree growth, with regard to eutrophication of habitats, in stands varied in tree density, or on the increase in stand growth and tree abundance (Socha and Orzeł 2013; Saarsalmi et al. 2014; Staniaszek and Socha 2015).

Climate change will strongly affect nitrogen flow. Drought increases soil aeration and thus makes conditions unfavorable for $\mathrm{N}_{2} \mathrm{O}$ production by denitrification (Castaldi 2000).
Fig. 4 Diagram illustrating ectomycorrhiza of Aureoboletus projectellus (a) with extramatrical mycelium (b) and Pinus sylvestris fine root (c). Extramatrical mycelium penetrates the capillary spaces of parent soil particles (1), mineral (2) and organic (3) compounds filled with water solution (M. Wrzosek)

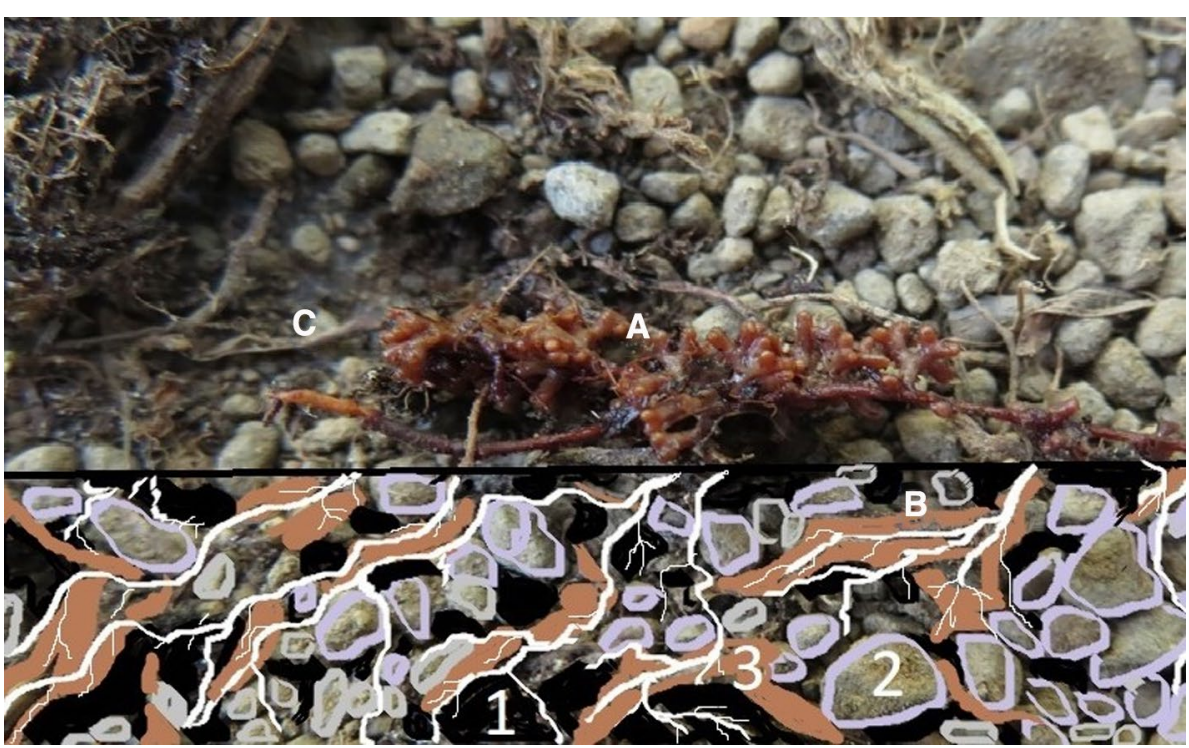


The projected changes in precipitation and temperature will affect emissions of $\mathrm{N}_{2} \mathrm{O}$ and $\mathrm{NO}$ from the soil. Also, drought limits the overall activity of soil microorganisms, reducing the amount of $\mathrm{N}$ cycled in the ecosystem (Kieft et al. 1987) and promotes nitrogen accumulation in forest soils by reduction of the litter decomposition rate (Wieder et al. 2009). Also, Sanaullah et al. (2012) found that drought reduced the release of $\mathrm{C}$ and $\mathrm{N}$ from litter by more than $50 \%$. For EM mycelium, soil nitrogen is absorbed in the form of both organic and mineral nitrogen; nitrogen is transferred to roots and other tree tissues, promoting plant development, and participating in biomass production. Nitrogen is particularly easily absorbed as ammonium, which is released from the soil substrate with the fungal enzyme glutamine synthetase and transferred to root cells in the form of the amino acid glutamine, which is necessary in many nitrogen cycles and in protein biosynthesis (Marschner and Dell 1994). Excess nitrogen in the soil solution increases its absorption by hyphae, but at the same time causes the consumption of carbon from carbohydrates supplied by the host plant and affects EM equilibrium (Hobbie and Colpaert 2003). Global warming scenarios also project an increase of nitrogen in forest ecosystems due to its airborne deposition and use of fertilizers. The presence of fungi can improve the equilibrium removing nitrogen (predominantly in organic form) from the soil. Some field studies show the phenomenon of the decrease of inorganic nitrogen level in soil with elevated temperatures (Lilleskov et al. 2002; Avis et al. 2008; Pickles et al. 2012). The presence of fungi which can link plants with organic sources of nitrogen can be especially desired.

\section{Water transport under drought}

Mycelium of the ectomycorrhizal fungus penetrates the capillary spaces (pores) between the mineral-organic structures that form the soil, acquiring water and soluble mineral compounds by osmosis. The transport of water from the soil to the leaves occurs through an unbroken column of water from the soil into the cells of the fungus, from there into root cells, then into water conducting xylem tissues up to the leaves. Transpiration taking place during the day in the leaf creates a water potential gradient that induces the influx of water from the soil into the fungus hyphae network and up the tree to the transpiring leaves (Egerton-Warburton et al. 2007a, b). The hyphal networks produced by ectomycorrhizal fungi are apparently adapted for water transport (Johnson 2018). The total length of mycorrhizal mycelium on a tree root system can reach hundreds of meters in length, with up to $4000 \mathrm{~m}$ of hypha per linear meter of roots (Read and Boyd 1986). For example, hyphae of Suillus bovinus can reach a total of $200 \mathrm{~m}$ in $1 \mathrm{~g}$ of soil, with the length of single hyphae of Thelephora terrestris reaching up to $20 \mathrm{~cm}$, and Pisolithus tinctorius hyphae can extend up to $42 \mathrm{~cm}$ from a mycorrhizal root (Hilszczańska and Sierota 2005; Nedelin 2014). Early studies using isotopically labeled water provided evidence that rhizomorphs of $S$. bovinus facilitated apoplastic transport of water through their central vessels. This transport was directed to several plants connected to the hyphal network and was especially efficient for coniferous seedlings (Duddridge et al. 1980). Based on pioneering early work by Duddridge et al. (1980) and Brownlee et al. (1983), sets of experiments have been developed to demonstrate how common mycorrhizal networks (CMNs) can facilitate interplant transfer of water between seedlings both in the field (Warren et al. 2008) and in laboratory (Egerton-Warburton et al. 2007a, b).

Mycorrhizal fungi often form a symbiosis with different tree species, so the extrametrical mycelium creates a type of mycorrhizal system, where young seedlings benefit from being connected with older trees (Dighton and Mason 1985; Agerer et al. 2012). In a state of soil water deficiency, young mycorrhizal plants can fix $\mathrm{CO}_{2}$ at a rate ten times greater than that of non-mycorrhizal seedlings, as shown by Parke et al. (1983).

Water is a good solvent due to its polar properties and differences in solute concentrations across semipermeable cell membranes create a cellular osmotic potential gradient that can cause water and ion movement. Ions can also move against an osmotic gradient through protein ion channels or protein conveyors. Leaf transpiration, driven by differences in water potential of air and stomata of leaves, is the driving force of passive transport by diffusion. According to Lheto and Zwiazek (2011), water transport occurs via the symplast in at least five pathways, via plasmodesmata connecting protoplasts in adjacent cells, and via the apoplast along cell walls. During dry periods, when osmotic concentrations of the soil solution may exceed those in the mycelium, active transport occurs in which the ion concentration gradient is overcome by ATP regulation. An essential energy carrier of the then-activated proton and/or ion pumps is ATPase, in the mycelium and root cells. Active transport regulates the amount of nitrogen and phosphorus in the cellular structures of the fungus and root cells (Lum and Hirsch 2002; Krajinski et al. 2014). Drought is, in consequence, a period of intensive energy consumption and only plants and fungi storing the supply can survive harsh time. The fungi store energy in the form of oil and glycogen. If a part of the mycorrhizal net is richer in these compounds than others, it can be available to other fungi and plants, as long as the mineral and energy compounds are translocated by hyphae. The high stoichiometric status of $\mathrm{N}: \mathrm{P}$ is also recognized as a factor influencing transport of mineral compounds from plant to plant via mycelium (Mariotte et al. 2017).

Mycorrhizal systems, however, are subject to damage for many reasons, not only related to natural death, but also due to external disturbances, such as pathogens, 
consumers, mechanical damage, or toxins. An important element in these processes is the disruption or cessation of the water and ion uptake due to drought. The presence of root pathogens is an important factor reducing root water uptake. These pathogens do not directly colonize fine roots, but by infecting woody, thicker parts, they cause the death of living tissues, including phloem. Infection of thicker roots and cell degradation caused by the pathogen's enzymes cuts off access to carbohydrates for the mycorrhizal mycelium, which in turn reduces water transport to this part of the root system (Graham 2001; Piri 2003). There are some remarkable reports (e.g., Simard 2016; Defrenne and Simard 2019) of trees in conditions of moisture deficiency surviving harsh time due to the link to the mycorrhizal net. Water not only is a carrier of ions and other metabolic compounds in trees, but more importantly is an electron donor in photosynthesis (Kopcewicz and Lewak 2019). Transpiration regulates the thickness of cuticles and stomata in the lower surface of leaves or needles. Water vapor transpiring through stomatal apertures cools the surface of the leaves on the one hand and regulates the water status of the plant on the other. Wind, insolation, and humidity, as well as soil water content, significantly affect transpiration (e.g., Taiz and Zeiger 2006). Stomatal closure in the event of drought regulates water loss by perennial woody plants. The opening of stomata occurs when there is increased turgor in the guard cells due to the influx of water. This influx is, in turn, the result of ionic changes in the stomata due to glucose loss, caused by its breakdown or natural use (Daszkowska-Golec and Szarejko 2013). Drying of the tree crown influences the state of the roots and mycorrhizal partners, and vice versa (De Boer and Volkov 2003; Kopcewicz and Lewak 2019). In conditions of increasing soil drought and changes in the ionic concentration of the soil solution, progressive changes in the activity of mycorrhizal mycelium also determine physiological and pathogenic changes within the crown. This activates coexisting endophytic fungi and pathogens first of all.

\section{Endophytes and drought}

Endophytes inhabit practically all parts of plants, from roots to shoots and leaves. Endophytic fungi have been classified into two broad groups (clavicipitaceous and non-clavicipitaceous) based on their phylogeny and life history traits (Rodriguez et al. 2009). The clavicipitaceous endophytes are all phylogenetically related and proliferate within cool and warm season grasses (Saikkonen et al. 2016). The nonclavicipitaceous endophytes which are from woody plants belong to the Ascomycota or Basidiomycota group (e.g., Sieber 2007; Watkinson 2016). They are significant for plants due to their common occurrence in forest stands and performing important physiological and ecological functions
(Arnold 2007; Unterseher 2011; Witzell and Martín 2018; Hodkinson et al. 2019). Endophytic fungi colonizing leaves or shoots cause various biochemical effects on their hostwhen water is scarce, endophytic fungal enzymes consume nutrients from the cells of the tree, which reduces the activity of plant cells and can cause, for example, chloroplast degradation and chlorophyll destruction, magnesium deficiency and nitrogen excess (Schulz et al. 2002; Mousa and Raizada 2013). Endophytes, on the other hand, are conversely activated under unfavorable conditions in the production of gibberellins or many other compounds (Arnold 2007, 2008; Kusari et al. 2012; Khan et al. 2015). Root endophytic fungi, unlike mycorrhizal fungi, colonize all parts of the internal root system, which means that their biomass is even higher than that of mycorrhizal fungi (Grünig et al. 2006, 2011; Bartnik 2013). However, because they can improve the nutrient status and water balance of the host plant (Likar 2018), their role in plant development is no less important than that of mycorrhizal fungi (Hilszczańska 2016; Stroheker et al. 2018; Khullar and Reddy 2019; Rana et al. 2019; Landolt et al. 2020).

Interactions between host and endophyte species are forms of mutualistic symbiosis or commensalism, but visible symptoms arise when plants are under stress (Watkinson 2016). Endophytic organisms usually benefit their hosts by increasing plant stress tolerance (Rodriguez and Redman 2008 ), or by reducing the possibility of insect attack by producing toxic alkaloids (Zhang et al. 2012; Lugtenberg et al. 2016), or by reducing infection of plant tissues by pathogens due to antagonism (Arnold et al. 2003). However, some endophytic fungi, depending on the fungal development stage, plant growth phase, weather and environmental factors and host reaction, can become pathogens (Schulz and Boyle 2005; Sieber 2007). In recent years, one of the most important abiotic factors damaging European forests directly and indirectly (activation of needle and stem endophytes) has been water shortage. It was associated with long periods of drought and accompanying high air temperatures (Allen et al. 2010; Sierota et al. 2019) what changed the balance between plant and an endophytic fungus. An example of a fungus with an endophytic stage found in the shoots and needles of Pinus spp., which is activated by water stress, is Cenangium ferruginosum (Fig. 5a). Its presence can cause pine dieback when conditions become favorable to the fungus or unfavorable to the host (Jurc et al. 2000), although Ryu et al. (2018) did not show a direct effect of drought on the induction of $C$. ferruginosum pathogenicity. However, they found that under water deficit, the resistance to infection of pine decreases as well as the presence of some terpenoids, flavonoids, and phenolic acids (Jurc et al. 2000; Kunca and Leontovyč 2013b). At the same time, accumulation of abscisic and jasmonic acids in plant is observed (Ryu et al. 2018). This condition of the tree facilitates the 


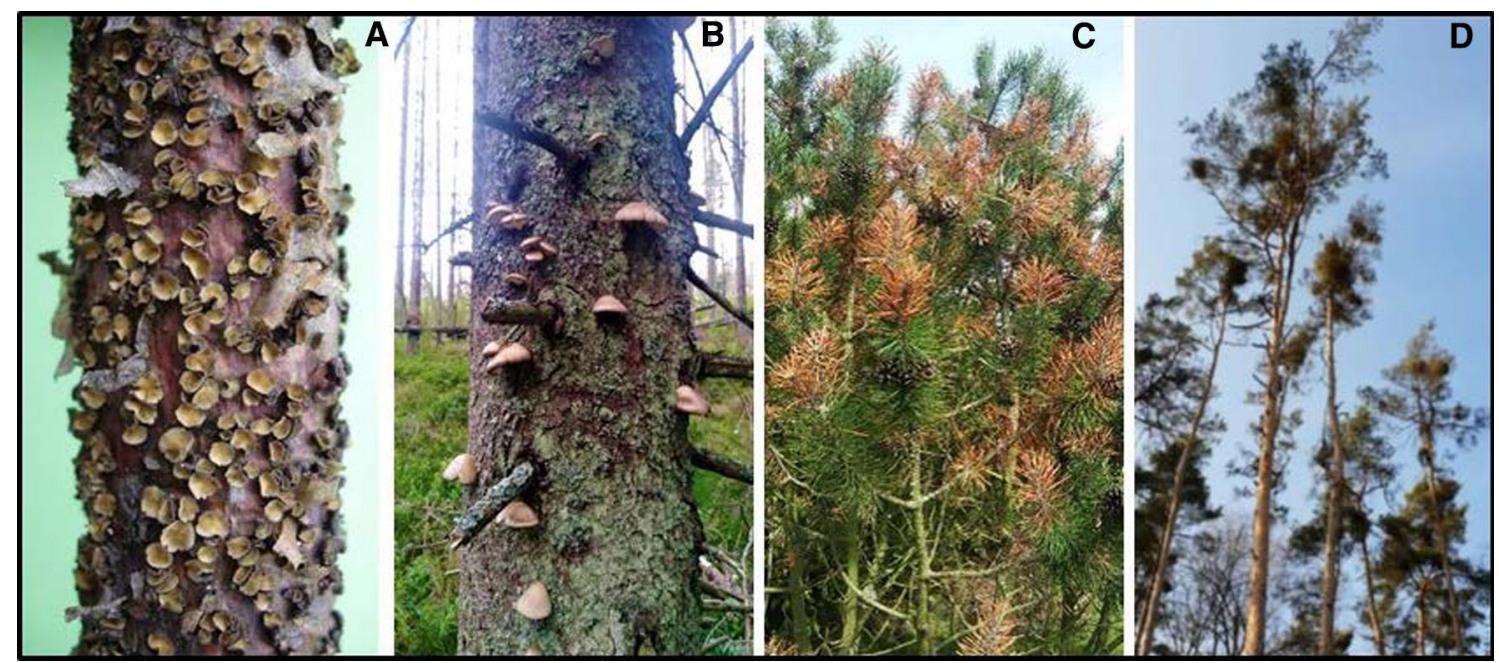

Fig. 5 a-Numerous apothecia of Cenangium ferruginosum on a branch of a dead Pinus sylvestris previously weakened by drought (Photo: A. Szczepkowski); b-Pleurotus abieticola basidiomata occurring on standing spruce after drought and infestation by spruce bark beetles, Tatrzański National Park, 2019 (Photo: M. Wrzosek);

growth and development of $C$. ferruginosum and causes a change in its biology. The fungus shifts from endophytic phase to phytopathogenic and saprotrophic lifestyle (Kunca and Leontovyč 2013a, b). Sphaeropsis sapinea (syn. Diplodia sapinea) causing Diplodia tip blight (shoot dieback of conifers) (Fig. 5c) is also a relevant example of fungus which can change its lifestyle from endophytic to pathogenic when climatic conditions change with precipitation deficits and increased temperatures. The mentioned climatic conditions that weaken trees, together with the properties of $S$. sapinea, probably are largely responsible for its rapid spread and increasing coniferous forest health problems in Northern and Central Europe (Fabre et al. 2011; Brodde et al. 2019; CABI 2019; Sierota et al. 2019; Bußkamp et al. 2020; Szczepkowski et al. 2021).

In Poland in the end of the twentieth century, the largescale death of Scots pines (ca. 1 million ha) was a consequence of frost drought at the end of winter. Rapid transition from low to warm temperatures, which evoked high rates of transpiration in the needles and simultaneously a lack of water provided by root systems because of still frozen soil was catastrophic for trees (Kowalski 1997; Sierota 2011; Sierota et al. 2019). At the same time, there were large-scale outbreaks of the endophytes Thyronectria cucurbitula and C. ferruginosum, and the damaging insect Contarinia baeri (Sierota et al. 1998).

Adverse environmental conditions usually do not occur singly, but often arrive with other unfavorable conditions or they arrive one after another. One consequence of dry and hot conditions is an increased occurrence of forest fires. In Poland in just one year of 2019 over 9,600 forest fires were c-crown of Pinus mugo growing in water deficiency and infected by Sphaeropsis sapinea (Photo: A. Szczepkowski), d-droughted Scots pines with numerous mistletoe in the crown (Photo: courtesy by K. Nowik). Photos at different magnifications

recorded (Zajączkowski et al. 2020). Pine trees, weakened not only by water stress but also damaged by fire, may be subsequently attacked by numerous occasional weak parasites and pathogens, including endophytic fungi, such as $C$. ferruginosum, Pezicula cinnamomea, Thyronectria spp., Valsa pini, and Therrya spp. (Gierczyk et al. 2019) and root decay fungi, e.g., Heterobasidion annosum and Rhizina undulata (Tyburski et al. 2019). The higher temperature as a factor changing the plants' response to the pathogens is broadly discussed by Desaint et al. (2021). Pine trees growing beyond their natural range may be particularly susceptible to C. ferruginosum (Kowalski and Domański 1983; Kowalski 1997; Jurc et al. 2000). In Europe, this applies primarily to Pinus nigra, whose admixture in Pinus sylvestris stands may be the primary source of infection giving rise to damaging dieback of $P$. sylvestris shoots (Kowalski 1997; Jurc et al. 2000). The forests growing on quasi- natural stands and composed by native plants are much more resistant to the changes (Manion 1991; Sierota 2011; Jactel et al. 2017).

\section{Phytopathogens and entomopathogens under drought}

The lack of water in the soil stresses trees physiologically and stimulates the development of root pathogens. Kubiak et al. (2017) provide extensive literature describing the impact of drought and climate change on the pathogenesis of Armillaria spp. When discussing the impact of drought on tree-pathogen relationships, one should not ignore the 
pests in the 'Spruce-Armillaria-Ips typographus 'syndrome (Sierota and Grodzki 2020). It has been shown by Netherer et al. (2019) and Mezei et al. (2017) that drought and high temperature greatly weaken trees and influence bark beetle activity in spruce stands in the Austrian mountains. This phenomenon is also observed in Poland, particularly in the Białowieża Forest and in spruce stands in the Tatra Mountains. Favorable conditions for the aggregation of bark beetles last only a few days. The beetles receive a volatile signal secreted by a weakened tree (phenolic compounds, oleoresins) which is an impulse to aggregate the community (Lieutier 2002). The chemical compounds are emitted by mycelium both of Armillaria spp. (Lung-Escarmant and Guyon 2003), and members of Ophiostomatales associated with beetles (Jankowiak and Hilszczański 2005). Some authors show that volatile compounds of the decomposed phloem and wood, has a pheromonal effect on females (Krokene and Solheim 1997; Vega and Blackwell 2005). Referring to the Janzen-Connell -effect (Liang et al. 2015), it can be assumed that fungi and beetles play the role of selection factors for trees in the artificial ecosystem with excessive proportion of spruce, as observed in many commercial stands. However, it is observed that the influence of bark beetles is much less pronounced in natural stands.

The occurrence of Pleurotus abieticola has recently been observed as an indirect result of drought in Poland. This rare fungus appears on spruce trees several years after infestation of spruce bark beetles (Fig. 5b). This recent phenomenon seems connected with climate change because the sudden infection of spruce by this fungus was not previously documented, and the fungus is formerly known to occur on only a few sites in Poland (Kujawa et al. 2017; Gierczyk et al. 2018; Żółciak 2019). The sporocarps of many fungi known from their endophytic growth appear after water movement through xylem vessels stops (Boddy et al. 2017). An excellent example of fungal response for water deficiency is the presence of Schizophyllum commune fruitbodies, which occur along the entire length of the tree' stem just after the tree death. S. commune is a wound parasite on living trees, e.g., after bark fire damage or old sunscorch. This fungus tolerates both heat and desiccation (Butin 1995; Schmidt 2006; Boddy and Heilmann-Clausen 2008; Takemoto et al. 2010).

Common ash (Fraxinus excelsior) is an important tree species in Europe, distributed from Iran to Ireland and from southern Scandinavia to northern Spain (Kárpáti 1970). In the Białowieża National Park in Poland, losses of ash trees have reached up to 75\% (Miścicki 2016). The roots of Fraxinus species are predominantly colonized by arbuscular mycorrhizal (AM) fungi (Lyr et al. 1992; Weber and Claus 2000). Although the roots of AM tree species are less sensitive to drought than those of EM trees (Liese et al. 2019), mycorrhizal fungi cannot adequately protect Fraxinus from the damage caused by rapidly developing fungi in the canopy what is eventually a reason for the ash-dieback.

As another indirect consequence of increasing drought on deciduous trees, pathogens such as members of the Ophiostomatales may be more vital during periods of tree stress (Pautasso et al. 2013), being lethal for individual trees or even entire stands (Jankowiak and Hilszczański 2005; Pandey et al. 2015; Terhonen et al. 2019). Although Fraxinus spp. are considered shade and waterlogging tolerant, remarkably high air temperatures and low humidity can activate some pathogens that appear on young regrowth such as Diplodia mutila, Phomopsis spp. and Cytospora spp. of weakened trees (Przybył 2002; Kowalski, Łukomska 2005, Kowalski 2007a, b). However, in the case of ash F. excelsior dieback in Europe, Hymenoscyphus fraxineus (syn. Chalara fraxinea) plays a leading role in pathogenesis. However, as several authors mention, high temperatures on the forest floor in summer are not conducive to growth and sporulation during the development of $H$. fraxineus ascomata (Ghelardini et al. 2017; Grosdidier et al. 2018; Hietala et al. 2018), but they may reappear in autumn after a period of high temperatures. The infection of shoots with the pathogen is less likely during prolonged dry periods, but the pathogen usually persists on pseudosclerotic petioles in some years (Kirisits 2015). The problem is still open, particularly since Díaz-Yáñez et al. (2020), in turn, question the influence of drought on ash development and survival.

Attention is also drawn to the growing problem of mistletoe in forests. Viscum album subsp. austriacum is observed in Scots pine stands in Poland, V. album subsp. album occurs on different deciduous trees or V. album subsp. abietis on fir (Plagnat 1950; Zuber 2004; Szmidla et al. 2019). This hemiparasite is indicated in Poland by crown thinning and death of Scots pine trees during drought, most often in older stands The intense occurrence of mistletoe also limits the activity of mycorrhizal roots by a shortening carbohydrates supply from dying tree crowns, worsening its water balance and accelerating drought symptoms (Barbu 2010; Szmidla et al. 2019; Billigly et al. 2018; Skrypnik et al. 2020). Gehring and Whitham (1991) found a significant impact of Juniperus mistletoe (Phoradendron juniperinum Engelm.) on root mycorrhizal status and noted greater dieback of trees than those without mistletoe, despite growing under the influence of water and nutrient deficiency. Cullings et al. (2005) suggested that mistletoe in the tree canopy not only selects ectomycorrhizal species in tree roots, but also affects soil microbial activity and the local ecosystem. It is worthy adding that some pathogens of the V. album e.g., Sphaeropsis $v i s c i$, which is a quite common species in Central Europe (Gierczyk et al. 2019; Tkaczyk and Sikora 2020), can be a natural barrier to mistletoe spreading. Chen et al. (2018) reports that this pathogen decreases the Asian mistletoe fitness. 
The drought is a period of extensive activity of many plant consumers especially from Hymenoptera, Lepidoptera, and Homoptera orders. The insects protected by chitinous exoskeletons are less sensitive to insolation. Moreover, some insects and mites forage under the epidermis or inside plant tissues where they are protected from drying out. It seems that the influence of drought leads to an increase in herbivorous insect populations and disproportionate mortality of trees (Anderegg et al. 2015). Contrary, the period of drought is extremely unfavorable for some entomopathogens. Fungi of the order Entomophthorales, which are normally especially useful in insect regulation, are unable to adapt to water shortages and are practically absent in their active stage during dry seasons (Delalibera et al. 2000). The authors found that the humidity (RH) favorable for development of Neozygites spp.-parasite of mites feeding on cassava-is 70-79\%, which means that during dry periods Neozygites spp. is observed only as dormant spores or hyphal bodies within dead individuals. The biological control of plant parasitic insects should be therefore during dry seasons focused rather on fungi belonging to Ophiocordycypitaceae and relatives (Lacey 2017).

\section{The methods of counteracting changes in the population of fungi involved in interactions with plants}

\section{The protection of old-growth forest stands}

During a deepening period of water deficit, the first trees to be affected are those that are not enough adapted to water stress, as well as those with inefficient ectomycorrhizal associates and trees already weakened by biotic factors and thus their removal should be treated as a factor of natural selection (Desprez-Loustau et al. 2006). The death of such trees increases access to light and moisture in the forest floor, which is undoubtedly beneficial for natural regeneration. However, prolonged droughts with high temperatures can lead to large-scale forest dieback. On fertile sites with abundant water, trees sparingly form ectomycorrhizal systems, or create endotrophic mycorrhizal systems, as in the case of ash or poplar (Danielson and Polle 2014). As a result, in the event of a water deficit in these habitats, such systems can be prone to damage due to dieback of mycorrhiza (Liu et al. 2015). The strong effects of drought are seen especially in stands planted during the post-war afforestation of former agricultural land in many countries of central Europe (former East Germany, Poland, Ukraine, Belarus, and Lithuania). In Poland, post-agricultural afforestation currently accounts for almost 2 million hectares of land, which is close to $22 \%$ of total forest area (Sierota et al. 2019). A characteristic feature of the soils in these afforested lands is a shallow plow layer of soil previously cultivated for agriculture, completely different in physico-chemical and biotic structure than old forest soils, and the presence of a hard pan layer, sometimes containing high levels of iron and manganese (Smal and Olszewska 2008; Laganiere et al. 2010). The hard pan hinders the development of taproots of many tree species (e.g., Scots pine, larch, birch and oak) and encourages the development of a shallow, horizontal root system. Such root systems mainly use water from the upper soil layer, rather than accessing moisture that is present deeper in the ground, and in conditions of low precipitation and high air temperatures they quickly dry out, heat up, and, in winter, freeze (Raitio 2000; Bakker et al. 2006; Gurskaya and Shiyatov 2006). This can lead to damage of mycorrhiza, as well as to structural changes in the roots themselves (Sutinen et al. 1996; Cleavitt et al. 2008), which promotes the development of root pathogens and causes shoot damage (Schoeneweiss 1981; Marcais and Breda 2006; Elad and Pertot 2014). According to the present forest policy (Bernadzki 1990; Hausler and Scherer-Lorenzen 2001; Brzeziecki 2008) and increasing role of natural regeneration in managed forests (Peterken 1999; Bürgi 2015), such man-made interventions - costly and against near-to-nature forestry-are rare. The protection of old-growth forests, the avoiding of clearcuttings, and the sustaining of biodiversity in the level of forest trees as well as of forests microbiota are the easiest way to avoid the strong drought damages.

\section{Prevention of water drainage and afforestation policy with special interest on stress-tolerant trees}

Forest stands may be adapted to avoid drought caused by climate change by preventing the outflow of water in streams and small rivers, which increases soil moisture in nearby stands. Such treatments should be preceded by detailed environmental assessments, as the risk of failure of such approaches can be high. Adaptation of stands to climate change may also be done by favoring regeneration by tree species more resistant to drought or those that consume less water. The number of such tree species that also produce commercially valuable wood on poor sandy soils is rather limited. The introduction of non-native species also carries risks (Thuiller et al. 2008; Lindner et al. 2010). The share of birch in a stand often indicates the possibility of lower soil moisture on the site. Bernadzki (1990) showed that soil moisture content under a birch stand is lower than under other tree species, which is explained by the strong transpiration by birch, drying the soil due to high rates of tree water uptake. Sandy mugwort soils show the lowest water holding capacity, both capillary and field; brown soils hold slightly higher amounts of water and black soils, and muds hold the greatest amount of water (Musierowicz and Król 1962). Birch, as a pioneer 
species, occupies any above-mentioned soils, and even on infertile podzol soils it creates an extensive root system. The root system forms mycorrhizal associations, often with Amanita muscaria, Lactarius pubescens, Paxillus involutus or Hebeloma crustuliniforme. Therefore, mycorrhiza helps a tree occupying a poor habitat by improving water supply. The fungi in the next step can easily enter in contact with seedlings with other tree species. The presence of the rich, natural, or quasi-natural forests next to the new stand provides access to the spores of mycorrhizal fungi, which are disseminated by wind and animals. Forestry management should involve extending the existing forest complexes and creating green corridors rather than establishment of new separated stands. Adapting stands to drought can be achieved by eliminating inter- and intraspecific competition between trees and other vegetation for water (Parmesan 2006). Stand thinning can increase water availability for the remaining trees. However, eliminating competition by non-commercial forest vegetation, including many widespread non-commercial tree species in lowland coniferous forests, such as black cherry known also as American bird cherry (Prunus serotina) would be challenging (Horgan et al. 2003).

\section{The stimulation of mycorrhization}

Gehring et al. (2017) found that ectomycorrhizal community composition is under strong plant genetic control. The ECM communities should be therefore designed to the particular genotypes, or some artificially obtained tree clones easily entering in the symbiosis should be planted as necessary addition during afforestation practices. It was showed that the growth of artificially mycorrhized Pinus sylvestris seedlings with Thelephora terrestris inhabiting dry environments is much faster than non-mycorrhizal seedlings (Hilszczańska and Sierota 2006). This suggests that forests around the world with poor diversity of mycorrhizal association are more vulnerable to the warmer and drier climates predicted for the future (Pilosof et al. 2017). The artificial mycorrhization with using of media (ex. hemp seeds) containing the mycelium are rather not effective due to natural colonization of roots and artificial media by different fungi and bacteria. The planting of seedlings with developed mycorrhiza should give much better results. In pine European forests the mycorrhization using Scleroderma citrinum, and Rhizopogon spp. seems to be promising (Duñabeitia et al. 2004; Dučić et al. 2008).

\section{Perspectives}

The impact of the drought could be avoided using irrigation and rationing water for use in forests from water stored in catchments around forests. By using small water retention means, the natural retention capacity increases, which contributes to the potential for an increased amount of water that can be naturally stored and used in the forest. We are not able to regulate completely these processes, but the care of peatlands and bogs in the forests is one of the easiest ways to catch water in landscape and soil. The question for the forestry community is what can be done to reduce the effects of drought by improving the mycorrhizal status of trees? Since ectomycorrhizal fungal community composition ultimately determines the functionality of a fine-root system, the question seems to be fundamental. On the other hand, endophytes are a potential source of biological agents for controlling pests and diseases of seeds and mature plants. The growing interest in these organisms is heading toward their use in biological plant protection (e.g., Blumenstein et al. 2015; Terhonen et al. 2018; Verma and White 2019).

What is the possibility of adapting species composition, both of mycorrhizal and endophytic fungi as well as tree species, to water shortage? Is it possible to use mycorrhiza to help regenerate stands in drought prone, nutrient poor habitats, such as former agricultural land or formerly forested dune areas? The answer should be sought in local small retention, creation, and restoration of engineering structures with backwater devices (culvert-penstock, dike), adequate drainage in areas around the forest, or in the planting of trees with artificial and natural mycorrhization, as it is shown by Szabla and Pabian (2009).

It should be remembered that trees that currently are naturally producing seedlings to form future stands will themselves grow for several more decades and will be exposed to changes in climate much greater than have occurred to date. It is, therefore, necessary to consider mitigation, the reduction in greenhouse gas emissions, as well as adaptation, and to move away from petroleum products and replace them with natural renewable materials.

These challenges caused by climate change may lead to a change in the primary goal of forest management to that of being simply to maintain the natural functions of forests. Climate change may therefore force the development of entirely new models of forest management (Härkönen et al. 2019). Guy Ryder-UN-Water Chair at the 24th UN-Water Meeting in Geneva, 2016 stated that „There is no life without water"-but it is not the entire truth-"There is no forest without fungi" and any effort to improve forest conditions must take the state of the local mycobiota into account.

Acknowledgements The authors thank the Forest State Holding (DGLP) for field data, the Warmia and Mazury University for the 
statutory funds (Project 30.610.019-110), National Science Center NCN for the funds (Project No. 2016/23/B/NZ8/00897) and the anonymous reviewers for their valuable comments and suggestions.

Authors' contributions $\mathrm{AB}$ generated the meteorological field data; all authors substantially contributed to conceptualization, resources, writing the original draft, review and editing the text. ZS, DH and MW provided the general concept for the project.

Funding This paper was partially supported by the State Forest Holding in Poland (Project No. 500 426; Contract Number OR.271.3.4.2015), National Science Center NCN (Project No. 2016/23/B/NZ8/00897) and by statutory funds of the Forest Research Institute, the University of Warsaw, the Warsaw University of Life Sciences-SGGW, and the Warmia and Mazury University in Olsztyn, Poland.

Availability of data and material Not applicable.

Code availability Not applicable.

\section{Declarations}

Conflict of interest Authors declare no personal circumstances or interests that may be perceived as inappropriately influencing the representation or interpretation of reported research results.

Open Access This article is licensed under a Creative Commons Attribution 4.0 International License, which permits use, sharing, adaptation, distribution and reproduction in any medium or format, as long as you give appropriate credit to the original author(s) and the source, provide a link to the Creative Commons licence, and indicate if changes were made. The images or other third party material in this article are included in the article's Creative Commons licence, unless indicated otherwise in a credit line to the material. If material is not included in the article's Creative Commons licence and your intended use is not permitted by statutory regulation or exceeds the permitted use, you will need to obtain permission directly from the copyright holder. To view a copy of this licence, visit http://creativecommons.org/licenses/by/4.0/.

\section{References}

Abdullah AS, Moffat CS, Lopez-Ruiz FJ, Gibberd MR, Hamblin J, Zerihun A (2017) Host-multi-pathogen warfare: pathogen interactions in co-infected plants. Front Plant Sci 8:1806. https://doi. org/10.3389/fpls.2017.01806

Abuzinadah RA, Read DJ (1989) The role of proteins in the nitrogen nutrition of ectomycorrhizal plants IV the utilization of peptides by birch (Betula pendula $\mathrm{L}$ ) infected with different mycorrhizal fungi. New Phytol 112(1):55-60. https://doi.org/10.1111/j.14698137.1989.tb00308.x

Acsai J, Largent DL (1983) Ectomycorrhizae of selected conifers growing in sites which support dense growth of bracken fern. Mycotaxon 16(2):509-518

Agafonova SA, Frolova NL, Krylenko IN, Sazonov AA, Golovlyov PP (2017) Dangerous ice phenomena on the lowland rivers of European Russia. Nat Hazards 88:171-188. https://doi.org/10. 1007/s11069-016-2580-x

Agerer R (2001) Exploration types of ectomycorrhizae. Mycorrhiza 11(2):107-114. https://doi.org/10.1007/s005720100108

Agerer R, Hartmann A, Pritsch K, Raidl S, Schloter M, Verma R, Weigt R (2012) Plants and their ectomycorrhizosphere: cost and benefit of symbiotic soil organisms. In: Matyssek R, Schnyder H, Oßwald W, Ernst D, Munch J, Pretzsch H (eds) Growth and defence in plants. Ecological studies (Analysis and Synthesis). Springer, Berlin. https://doi.org/10.1007/978-3-642-30645-7_10

Allen CD, Macalady AK, Chenchouni H et al (2010) A global overview of drought and heat-induced tree mortality reveals emerging climate change risks for forests. For Ecol Manag 259(4):660-684. https://doi.org/10.1016/jforeco.2009.09.001

Anderegg WRL, Hicke JA, Fisher RA et al (2015) Tree mortality from drought, insects, and their interactions in a changing climate. New Phytol 208(3):674-683. https://doi.org/10.1111/nph.13477

Arnold AE (2007) Understanding the diversity of foliar endophytic fungi: progress, challenges, and frontiers. Fungal Biol Rev 21(23):51-66. https://doi.org/10.1016/j.fbr.2007.05.003

Arnold AE (2008) Endophytic fungi: hidden components of tropical community ecology. In: Carson WP, Schnitzer SA (eds) Tropical forest community ecology. Wiley-Blackwell, West Sussex, UK, pp 254-271

Arnold AE, Mejía LC, Kyllo D et al (2003) Fungal endophytes limit pathogen damage in a tropical tree. Proc Natl Acad Sci USA 100(26):15649-15654. https://doi.org/10.1073/pnas.2533483100

Avis PG, Mueller GM, Lussenhop J (2008) Ectomycorrhizal fungal communities in two North American oak forests respond to nitrogen addition. New Phytol 179(2):472-483. https://doi.org/ 10.1111/j.1469-8137.2008.02491.x

Bakker MR, Augusto L, Achat DL (2006) Fine root distribution of trees and understory in mature stands of maritime pine (Pinus pinaster) on dry and humid sites. Plant Soil 286(1-2):37-51. https://doi.org/10.1007/s11104-006-9024-4

Banaszkiewicz B, Grabowska K, Panfil M (2008) Characterisation of atmospheric precipitation of Iława and ChełmińskoDobrzyńskie lake districts in the years 1951-2000. Acta Agrophys 13(3):575-585

Barbu C (2010) The incidence and distribution of white mistletoe (Viscum album ssp abietis) on silver fir (Abies alba Mill) stands from Eastern Carpathians. Ann for Res 53(1):27-36

Barnes CJ, Van der Gast CJ, McNamara NP, Rowe R, Bending GD (2018) Extreme rainfall affects assembly of the root-associated fungal community. New Phytol 220(4):1172-1184. https://doi. org/10.1111/nph.14990

Bartnik C (2013) Endofity korzeni świerka pospolitego oraz podatność drewna różnych jego pochodzeń na rozkład przez Armillaria ostoyae i Heterobasidion parviporum [The mycobiota of Norway spruce roots and susceptibility of its wood to decay by Armillaria ostoyae and Heterobasidion parviporum]. Zeszyty Naukowe Uniwersytetu Rolniczego im Hugona Kołłąaja w Krakowie 520 Rozprawy 397 Wydawnictwo Uniwersytetu Rolniczego w Krakowie, Kraków

Bernadzki E (1990) Koncepcje hodowli lasu na gruntach porolnych [Concepts of silviculture on post-agricultural lands]. Sylwan 134(3/12):51-59

Bilgili E, Ozturk M, Coskuner KA, Baysal I, Serdar B, Yavuz H, Eroglu M, Usta Y (2018) Quantifying the effect of pine mistletoe on the growth of Scots pine. For Pathol 48:e12435. https://doi. org/10.1111/efp.12435

Birhane E, Sterck F, Fetene M, Bongers F, Kuyper T (2012) Arbuscular mycorrhizal fungi enhance photosynthesis, water use efficiency, and growth of frankincense seedlings under pulsed water availability conditions. Oecologia 169:895-904. https://doi.org/10. 1007/s00442-012-2258-3

Blasius D, Feil W, Kottke I, Oberwinkler F (1986) Hartig net structure and formation in fully ensheathed ectomycorrhizas. Nord J Bot 6:837-842. https://doi.org/10.1111/j.1756-1051.1986.tb00487.x

Blumenstein K, Albrectsen BR, Martín JA, Hultberg M, Sieber TN, Helander M, Witzell J (2015) Nutritional niche overlap potentiates the use of endophytes in biocontrol of a tree 
disease. Biocontrol 60(5):655-667. https://doi.org/10.1007/ s10526-015-9668-1

Blunden J, Arndt DS, Baringer MO (2011) State of the climate in 2010. Bull Am Meteorol Soc 92(6):1-266

Boczoń A, Kowalska A, Dudzińska M, Wróbel M (2016) Drought in Polish forests in 2015. Pol J Environ Stud 25(5):1857-1862. https://doi.org/10.15244/pjoes/62797

Boddy L, Heilmann-Clausen J (2008) Basidiomycete community development in temperate angiosperm wood. In: Boddy L, Frankland JC, van West P (eds) Ecology of saprotrophic basidiomycetes. Elsevier Ltd., Amsterdam, pp 211-237

Boddy L, Hiscox J, Gilmartin EC, Johnston SR, Heilmann-Clausen J (2017) Wood decay communities in angiosperm wood. In: Dighton J, White JF (eds) The fungal community: its organization and role in the ecosystem. CRC Press, New York, pp 169-190

Bödeker ITM, Clemmensen KE, De Boer W, Martin F, Olson Å, Lindahl BD (2014) Ectomycorrhizal Cortinarius species participate in enzymatic oxidation of humus in northern forest ecosystems. New Phytol 203(1):245-256. https://doi.org/10. $1111 /$ nph. 12791

Bonfante P, Genre A (2010) Mechanisms underlying beneficial plant-fungus interactions in mycorrhizal symbiosis. Nat Commun 1:48. https://doi.org/10.1038/ncomms1046

Briffa KR, Van der Schrier G, Jones PD (2009) Wet and dry summers in Europe since 1750: evidence of increasing drought. Int J Climatol 29(13):1894-1905. https://doi.org/10.1002/joc.1836

Brodde L, Adamson K, Camarero JJ et al (2019) Diplodia tip blight on its way to the north: Drivers of disease emergence in Northern Europe. Front Plan Sci 9:1818. https://doi.org/10.3389/ fpls.2018.01818

Brownlee C, Duddridge JA, Malibari A, Read DJ (1983) The structure and function of mycelial systems of ectomycorrhizal roots with special reference to their role in forming inter-plant connections and providing pathways for assimilate and water transport. Plant Soil 71:433-443. https://doi.org/10.1007/ BF02182684

Brzeziecki B (2008) Podejście ekosystemowe i półnaturalna hodowla lasu w kontekśscie zasady wielofunkcyjności [Ecosystem approach and close-to-nature silviculture (in context of forest multifunctionality principle]. SiM CEPL 3:41-54

Bürgi M (2015) Close-to-nature forestry. In: Kirby KJ, Watkins C (eds) Europe's changing woods and forests: from wildwood to managed landscapes. CABI, Wallingford, pp 107-115

Burke EJ, Brown SJ, Christidis N (2006) Modeling the recent evolution of global drought and projections for the 21 st century with the Hadley centre climate model. J Hydrometeorol 7:1113-1125. https://doi.org/10.1175/JHM544.1

Bußkamp J, Langer GJ, Langer EJ (2020) Sphaeropsis sapinea and fungal endophyte diversity in twigs of Scots pine (Pinus sylvestris) in Germany. Mycol Prog 19:985-999. https://doi.org/10.1007/ s11557-020-01617-0

Butin H (1995) Tree diseases and disorders. Oxford University Press, Oxford

CABI (2019) Sphaeropsis sapinea (Sphaeropsis blight). Invasive Species Compendium. https://www.cabi.org/isc/datasheet/19160\# tosummaryOfInvasiveness. Accessed 22Nov 2020

Caloiero T, Veltri S, Caloiero P, Frustaci F (2018) Drought analysis in Europe and in the mediterranean basin using the standardized precipitation index. Water 10:1043. https://doi.org/10.3390/ w10081043CarfraeJA

Castaldi S (2000) Responses of nitrous oxide, dinitrogen and carbon dioxide production and oxygen consumption to temperature in forest and agricultural light-textured soils determined by model experiment. Biol Fertil Soils 32(1):67-72. https://doi.org/10. 1007/s003740000218
Chen J, Liu X, Jia H, Zhu W (2018) First report of leaf-spot disease caused by Sphaeropsis visci on Asian mistletoe (Viscum coloratum (Kom.) Nakai) in China. J for Res 29(6):1769-1774

Cleavitt NL, Fahey TJ, Groffman PM et al (2008) Effects of soil freezing on fine roots in a northern hardwood forest. Can $\mathrm{J}$ for Res 38(1):82-91. https://doi.org/10.1139/X07-133

Colpaert JV, Van Assche JA, Luijtens K (1992) The growth of the extramatrical mycelium of ectomycorrhizal fungi and the growth response of Pinus sylvestris L. New Phytol 120(1):127-135. https://doi.org/10.1111/j.1469-8137.1992.tb01065.x

Colpaert JV, Van Tichelen KK, Van Assche JA, Van Laere A (1999) Short-term phosphorus uptake rates in mycorrhizal and nonmycorrhizal roots of intact Pinus sylvestris seedlings. New Phytol 143(3):589-597. https://doi.org/10.1046/j.1469-8137. 1999.00471.x

Conway E, Arbuthnott M (1949) Occurrence of endotrophic mycorrhiza in the roots of Pteridium aquilinum Kuhn. Nature 163(4146):609. https://doi.org/10.1038/163609a0

Cosme M, Fernández I, Van der Heijden MGA, Pieterse CMJ (2018) Non-mycorrhizal plants: the exceptions that prove the rule. Trends Plant Sci 23(7):577-587. https://doi.org/10.1016/j.tplan ts.2018.04.004

Courty PE, Pritsch K, Schloter M, Hartmann A, Garbaye J (2005) Activity profiling of ectomycorrhiza communities in two forest soils using multiple enzymatic tests. New Phytol 167(1):309319. https://doi.org/10.1111/j.1469-8137.2005.01401.x

Courty PE, Buée M, Diedhiou AG et al (2010) The role of ectomycorrhizal communities in forest ecosystem processes: new perspectives and emerging concepts. Soil Biol Biochem 42(5):679-698. https://doi.org/10.1016/j.soilbio.2009.12.006

CTIF (2019) Scotland, Norway and Sweden already severely affected by forest fires due to the dry weather in the north International Association of Fire and Rescue Services CTIF https://www. ctif.org/news/scotland-norway-and-sweden-already-severelyeffected-forest-fires-due-dry-weather-north. Accessed 20Nov 2020

Cullings K, Raleigh Ch, Vogler DR (2005) Effects of severe dwarf mistletoe infection on the ectomycorrhizal community of a Pinus contorta stand in Yellowstone park. Can J Bot 83(9):1174-1180. https://doi.org/10.1139/b05-100

Danielsen L, Polle A (2014) Poplar nutrition under drought as affected by ectomycorrhizal colonization. Environ Exp Bot 108:89-98. https://doi.org/10.1016/j.envexpbot.2014.01.006

Daszkowska-Golec A, Szarejko I (2013) Open or close the gate - stomata action under the control of phytohormones in drought stress conditions. Fron Plant Sci 4:138. https://doi.org/10.3389/fpls. 2013.00138

Davi H, Cailleret M (2017) Assessing drought-driven mortality trees with physiological process-based models. Agric for Meteorol 232:279-290. https://doi.org/10.1016/j.agrformet.2016.08.019

De Boer AH, Volkov V (2003) Logistics of water and salt transport through the plant: structure and functioning of the xylem. Plant Cell Environ 26(1):87-101. https://doi.org/10.1046/j.1365-3040. 2003.00930.x

De Jalón LG, Limousin J-M, Richard F, Gessler A, Peter M, Hättenschwiler S, Milcu A (2020) Microhabitat and ectomycorrhizal effects on the establishment, growth, and survival of Quercus ilex $\mathrm{L}$ seedlings under drought. BioRXiv. https://doi.org/10.1101/ 2020.02.17.952549

Defrenne C, Simard S (2019) The secret language of trees. ehttps:// www.youtube.com/watch?v=V4m9SefyRjg. Accessed $20 \mathrm{Feb}$ 2020

Delalibera I Jr, Moraes GJ, Lapointe S et al (2000) Temporal variability and progression of Neozygites sp. (Zygomycetes: Entomophthorales) in populations of Mononychellus tanajoa (Bondar) (Acari: 
Tetranychidae). An Soc Entomol Bras 29(3):523-535. https://doi. org/10.1590/S0301-80592000000300015

Desaint H, Aoun N, Deslandes L, Vailleau F, Roux F et al (2021) Fight hard or die trying when plants face pathogens under heat stress. New Phytol 229(2):712-734

Desprez-Loustau ML, Marçais B, Nageleisen L-M, Piou D, Vannini A (2006) Interactive effects of drought and pathogens in forest trees. Ann for Sci 63(6):597-612. https://doi.org/10.1051/forest: 2006040

Díaz-Yáñez O, Mola-Yudego B, Timmermann V, Tollefsrud MM, Hietala AM, Oliva J (2020) The invasive forest pathogen Hymenoscyphus fraxineus boosts mortality and triggers niche replacement of European ash (Fraxinus excelsior). Nat Sci Rep 10:5310. https://doi.org/10.1038/s41598-020-61990-4

Dighton J, Mason PA (1985) Mycorrhizal dynamics during forest tree development. In: Moore D, Caselton LA, Wood DA, Frankland JC (eds) Development biology of higher fungi. Cambridge University Press, Cambridge, pp 117-139

Dosskey MG, Boersma L, Linderman RG (1991) Role for the photosynthate demand of ectomycorrhizas in the response of Douglas-fir seedlings to drying soil. New Phytol 117(2):327-334. https://doi.org/10.1111/j.1469-8137.1991.tb04914

Dubrovský M, Svoboda MD, Trnka M, Hayes MJ, Wilhite DA, Zalud Z, Hlavinka P (2009) Application of relative drought indices in assessing climate change impacts on drought conditions in Czechia. Theor Appl Climatol 96(1):155-171. https://doi.org/ 10.1007/s00704-008-0020-x

Dučić T, Parladé J, Polle A (2008) The influence of the ectomycorrhizal fungus Rhizopogon subareolatus on growth and nutrient element localisation in two varieties of Douglas fir (Pseudotsuga menziesii var. menziesii and var. glauca) in response to manganese stress. Mycorrhiza 18:227-239. https://doi.org/10. 1007/s00572-008-0174-5

Duddridge JA, Malibari A, Read DJ (1980) Structure and function of mycorrhizal rhizomorphs with special reference to their role in water transport. Nature 287:834-836. https://doi.org/10.1038/ $287834 \mathrm{a} 0$

Duñabeitia MK, Hormilla S, Garcia-Plazaola JI, Txarterina K, Arteche U, Becerril JM (2004) Differential responses of three fungal species to environmental factors and their role in the mycorrhization of Pinus radiata D Don. Mycorrhiza 14(1):1118. https://doi.org/10.1007/s00572-003-0270-5

Egerton-Warburton LM, Querejeta JI, Allen MF (2007a) Common mycorrhizal networks provide a potential pathway for the transfer of hydraulically lifted water between plants. J Exp Bot 58(6):1473-1483. https://doi.org/10.1093/jxb/erm009

Egerton-Warburton LM, Querejeta JI, Allen MF (2007b) Efflux of hydraulically lifted water from mycorrhizal fungal hyphae during imposed drought. Plant Signal Behav 3(1):68-71

Elad Y, Pertot I (2014) Climate change impacts on plant pathogens and plant diseases. J Crop Improv 28(1):99-139

Fabre B, Piou D, Desprez-Loustau M-L, Marçais B (2011) Can the emergence of pine diplodia shoot blight in France be explained by changes in pathogen pressure linked to climate change? Glob Change Biol 17(10):3218-3322. https://doi.org/10. $1111 / \mathrm{j} .1365-2486.2011 .02428 . x$

Fraňková R (2019) Measures taken as over 60 percent of Czech Republic hit by extreme drought. https://www.radio.cz/en/ section/curraffrs/measures-taken-as-over-60-percent-of-czechrepublic-hit-by-extreme-drought. Accessed 20 Feb 2020

Garbaye J (2000) The role of ectomycorrhizal symbiosis in the resistance of forests to water stress. Outlook Agric 29(1):63-69

Gehring CA, Whitham TG (1991) Reduced mycorrhizae on Juniperus monosperma with mistletoe: the influence of environmental stress and tree gender on a plant parasite and a plant-fungal mutualism. Oecologia 89:298-303
Gehring CA, Sthultz CM, Flores-Rentería L, Whipple AV, Whitham TG (2017) Tree genetics defines fungal partner communities that may confer drought tolerance. Proc Nat Ac Sci USA 114(42):11169-11174. https://doi.org/10.1073/pnas. 17040 22114

George E, Marschner H, Jakobsen I (1995) Role of arbuscular mycorrhizal fungi in uptake of phosphorus and nitrogen from soil. Crit Rev Biotechnol 15(3-4):257-270. https://doi.org/10.3109/ 07388559509147412

Ghelardini L, Migliorini D, Santini A, Pepori AL, Maresi G, Vai N, et al. (2017) From the Alps to the Apennines: possible spread of ash dieback in Mediterranean areas. In: Vasaitis R, Enderle $\mathrm{R}$ eds. Dieback of European ash (Fraxinus spp.) - Consequences and Guidelines for Sustainable anagement. Uppsala, Sweden: Swedish Univ Agr Sci:140-149

Gierczyk B, Ślusarczyk T, Szczepkowski A, Kujawa A (2018) XXIII Wystawa Grzybów Puszczy Białowieskiej Materiały do poznania mykobioty Puszczy Białowieskiej [The 23rd Exhibition of Fungi of the Białowieża Forest Materials to the knowledge of mycobiota of the Białowieża Primeval Forest]. Przegląd Przyrodniczy 29(2):9-57

Gierczyk B, Szczepkowski A, Ślusarczyk T, Kujawa A (2019) Contribution to knowledge of the mycobiota of Kampinos National Park (Poland): part 2. Acta Mycol 54(1):1116. https://doi.org/ 10.5586/am. 1116

Graham JH (2001) What do root pathogens see in mycorrhizas? New Phytol 149(3):357-359. https://doi.org/10.1046/j.1469-8137. 2001.00077.x

Grosdidier M, Ioos R, Marçais B (2018) Do higher summer temperatures restrict the dissemination of Hymenoscyphus fraxineus in France? For Path 48(4):e12426. https://doi.org/10.1111/efp. 12426

Grünig CR, Duo A, Sieber TN (2006) Population genetic analysis of Phialocephala fortinii sl and Acephala applanata in two undisturbed forests in Switzerland and evidence for new cryptic species. Fungal Genet Biol 43(6):410-421. https://doi.org/10.1016/j. fgb.2006.01.007

Grünig CR, Queloz V, Sieber TN (2011) Structure of diversity in dark septate endophytes: from species to genes. In: Pirttilä AM, Frank AC (eds) Endophytes of forest trees: biology and applications. Forestry sciences 80 . Springer, Berlin, pp 3-30. https://doi.org/ 10.1007/978-94-007-1599-8_1

Guehl JM, Garbaye J (1990) The effects of ectomycorrhizal status on carbon dioxide assimilation capacity, water-use efficiency, and response to transplanting in seedlings of Pseudotsuga menziesii (Mirb) Franco. Ann for Sci 47(6):551-563. https://doi.org/10. 1051/forest:19900602

Gurskaya MA, Shiyatov SG (2006) Distribution of frost injuries in the wood of conifers Russian. J Ecol 37(1):7-12. https://doi.org/10. 1134/S1067413606010024

Gutjahr C, Paszkowski U (2013) Multiple control levels of root system remodeling in arbuscular mycorrhizal symbiosis. Front Plant Sci 4:204. https://doi.org/10.3389/fpls.2013.00204

Hagedorn F, Joseph J, Peter M et al (2016) Recovery of trees from drought depends on belowground sink control. Nat Plants 2(8):16111. https://doi.org/10.1038/NPLANTS.2016.111

Härkönen S, Neumann M, Mues V et al (2019) A climate-sensitive forest model for assessing impacts of forest management in Europe. Environ Model Softw 115:128-143. https://doi.org/10.1016/j. envsoft.2019.02.009

Harley JL (1989) The significance of mycorrhiza. Mycol Res 92(2):129-139. https://doi.org/10.1016/S0953-7562(89)80001-2

Häusler A, Scherer-Lorenzen M (2001) Sustainable forest management in Germany: the ecosystem approach of the biodiversity convention reconsidered; Bundesamt für Naturschutz-Skripten 51. Bonn, Germany 
Hietala AM, Børja I, Cross H, Nagy NE, Solheim H, Timmermann V et al (2018) Dieback of European ash: what can we learn from the microbial community and species-specific traits of endophytic fungi associated with ash? In: Pirttilä AM, Frank AC (eds) Endophytes of forest trees: biology and applications. Forestry science. Springer, Cham, pp 229-258

Hilszczańska D (2009) Wpływ azotu w podłożu na cechy biometryczne oraz zawartość tego pierwiastka w siewkach sosny zwyczajnej $\mathrm{z}$ mikoryzą Thelephora terrestris [Influence of $\mathrm{N}$-fertilized substrata on biometric parameters and nitrogen content of seedlings with Thelephora terrestris]. Leśne Prace Badawcze/For Res Pap 70(1):19-25

Hilszczańska D (2016) Endofity - charakterystyka i możliwości wykorzystania w leśnictwie [Endophytes - characteristics and possibilities of application in forest management]. Leśne Prace Badawcze /For Res Pap 77(3):276-282. https://doi.org/10.1515/ frp-2016-0029

Hilszczańska D, Sierota Z (2005) Chemical composition of soil and ectomycorrhizal community structure in nursery as effect of watering. In: Pierzgalski E, Niemtur S, Czerepko J (eds) Protection of soil and water resources in forestry areas. Forest Research Institute, Warsaw, pp 57-63

Hilszczańska D, Sierota Z (2006) Persistence of ectomycorrhizas by Thelephora terrestris on outplanted Scots pine seedlings. Acta Mycol 41(2):313-318

Hilszczańska D, Małecka M, Sierota Z (2008) Changes in nitrogen level and mycorrhizal structure of Scots pine seedlings inoculated with Thelephora terrestris. Ann for Sci 65(4):409. https:// doi.org/10.1051/forest:2008020

Hobbie EA, Colpaert JV (2003) Nitrogen availability and colonization by mycorrhizal fungi correlate with nitrogen isotope patterns in plants. New Phytol 157(1):115-126. https://doi.org/10.1046/j. 1469-8137.2003.00657.x

Hodkinson TR, Doohan FM, Saunders MJ, Murphy BR (eds) (2019) Endophytes for a growing world. Cambridge University Press, Cambridge

Horgan T, Keane M, McCarthy R, Lally M, Thompson D (2003) A guide to forest tree species selection and silviculture in Ireland. COFORD, Dublin

InterSucho (2019) Drough intensity. https://www.intersucho.cz/cz/ mapy/intenzita-sucha/2-cerven-2019/?mapcountry=eu. Accessed 20 Feb 2020

IPCC 2013 Climate Change (2013) The physical science basis. In: Stocker TF (ed) Contribution of working group I to the fifth assessment report of the intergovernmental panel on climate change. Cambridge University Press, Cambridge

Jactel H, Bauhus J, Boberg J et al (2017) Tree diversity drives forest stand resistance to natural disturbances. Curr for Rep 3:223-243

Jankowiak R, Hilszczański J (2005) Ophiostomatoid fungi associated with Ips typographus L on Picea abies (L) H Karst and Pinus sylvestris L in North-Eastern Poland. Acta Soc Bot Pol 74(4):345-350. https://doi.org/10.5586/asbp.2005.043

Kopcewicz J, Lewak S (eds) (2019) Fizjologia roślin [Plant physiology]. Wydawnictwo Naukowe PWN, Warszawa

Johnson D (2018) Water, water everywhere but how does it affect the functional diversity of ectomycorrhizal fungi? New Phytol 220(4):950-951. https://doi.org/10.1111/nph.15086

Johnson NC, Wolf J, Reyes MA, Panter A, Koch GW, Redman A (2005) Species of plants and associated arbuscular mycorrhizal fungi mediate mycorrhizal responses to $\mathrm{CO}_{2}$ enrichment. Glob Change Biol 11(7):1156-1166. https://doi.org/10.1111/j.13652486.2005.00967.x

Jones MD, Durall DM, Linker PB (1990) Phosphorus relationships and production of extramatrical hyphae by two types of willow ectomycorrhizas at different soil phosphorus levels. New Phytol
115(2):259-267. https://doi.org/10.1111/j.1469-8137.1990.tb004 51.x

Jones MD, Grenon F, Peat H, Fitzgerald M, Holt L, Philip LJ, Bradley $\mathrm{R}$ (2009) Differences in ${ }^{15} \mathrm{~N}$ uptake amongst spruce seedlings colonized by three pioneer ectomycorrhizal fungi in the field. Fungal Ecol 2(3):110-120. https://doi.org/10.1016/j.funeco. 2009.02.002

Jurc D, Jurc M, Sieber TN, Bojovic S (2000) Endophytic Cenangium ferruginsoum (Ascomycota) as a reservoir for an epidemic of cenangium dieback in Austrian pine. Phyton 40(4):103-108

Kapoor R, Evelin H, Mathur P, Giri B (2013) Arbuscular mycorrhiza: approaches for abiotic stress tolerance in crop plants for sustainable agriculture. In: Tuteja N, Gill SS (eds) Plant acclimation to environmental stress. Springer Science+Business Media, Berlin/Heidelberg, pp 359-401. https://doi.org/10.1007/978-14614-5001-6_14

Kárpáti ZE (1970) Eine kritisch-taxonomische Übersicht der in Europa wildwachsenden Eschen-Arten und deren Unterarten [A critical taxonomic overview of wild ash species and their subspecies in Europe]. Feddes Repertorium 81(1-5):171-186

Karst J, Franklin J, Simeon A et al (2021) Assessing the dual-mycorrhizal status of a widespread tree species as a model for studies on stand biogeochemistry. Mycorrhiza 31:313-324. https://doi. org/10.1007/s00572-021-01029-2

Kennedy PG, Peay KG (2007) Different soil moisture conditions change the outcome of the ectomycorrhizal symbiosis between Rhizopogon species and Pinus muricata. Plant Soil 291(12):155. https://doi.org/10.1007/s11104-006-9183-3

Khan AL, Hussain J, Al-Harrasi A, Al-Rawahi A, Lee IJ (2015) Endophytic fungi: resource for gibberellins and crop abiotic stress resistance. Crit Rev Biotechnol 35:62-74. https://doi.org/10. 3109/07388551.2013.800018

Khullar S, Reddy MS (2019) Ectomycorrhizal diversity and tree sustainability. In: Satyanarayana T, Das S, Johri B (eds) Microbial diversity in ecosystem sustainability and biotechnological applications. Springer, Singapore, pp 145-166

Kieft TL, Soroker E, Firestone MK (1987) Microbial biomass response to a rapid increase in water potential when dry soil is wetted. Soil Biol Biochem 19(2):119-126. https://doi.org/10.1016/00380717(87)90070-8

Kirisits T (2015) Ascocarp formation of Hymenoscyphus fraxineus on several-year-old pseudosclerotial leaf rachises of Fraxinus excelsior. For Path 45:254-257. https://doi.org/10.1111/efp.12183

Körner Ch, Basler D, Hoch G, Kollas Ch, Lenz A, Randin ChF, Vitasse Y, Zimmermann NE (2016) Where, why and how? Explaining the low-temperature range limits of temperate tree species. J Ecol 104:1076-1088. https://doi.org/10.1111/1365-2745.12574

Kowalczyk A, Hrynkiewicz K (2018) Strigolactones as mediators between fungi and plants. Acta Mycol 53(2):1110. https://doi. org/10.5586/am. 1110

Kowalski T, Domański S (1983) Występowanie i przyczyny odwierzchołkowego zamierania pędów Pinus nigra, P. silvestris i P. strobus w niektórych drzewostanach południowej Polski w latach 1979-1980 [Occurence and source of the shoot top dieback of Pinus nigra, P. silvestris, and P. strobus in some forest stands in Southern Poland in 1979-1980]. Acta

Kowalski T, Łukomska A (2005) Badania nad zamieraniem jesionu (Fraxinus excelsior L.) w drzewostanach Nadleśnictwa Włoszczowa [The studies on ash dying (Fraxinus excelsior L.) in the Włoszczowa Forest Unit stands]. Acta Agrobotanica 58(2):429-440

Kowalski T (1997) Zamieranie pędów sosny [Pine shoots dieback] Biblioteczka leśniczego 80 Wydawnictwo Świat, Warszawa

Kowalski T (2007) Chalara fraxinea - nowo opisany gatunek grzyba na zamierających jesionach w Polsce [Chalara fraxinea - new 
described fungus species on dying ash in Poland] Sylwan 151 (4): 44-48. https://doi.org/10.26202/sylwan.2006066

Kowalski S (ed.) (2007) Ektomikoryzy. Nowe biotechnologie w polskim szkółkarstwie leśnym [Ectomycorrhiza. New technologies in Polish forest nurseries, in Polish]. Wydawnictwo Centrum Informacyjne Lasów Państwowych, Warszawa

Krajinski F, Courty P-E, Sieh D, Franken P, Zhang H, Bucher M, Gerlach N, Kryvoruchko I, Zoeller D, Udvardi M, Hause B (2014) The H+-ATPase HA1 of Medicago truncatula is essential for phosphate transport and plant growth during arbuscular mycorrhizal symbiosis. Plant Cell 26(3):1808-1817. https://doi.org/10. 1105/tpc. 113.120436

Krikken F, Lehner F, Haustein K, Drobyshev I, van Oldenborgh GJ (2019) Attribution of the role of climate change in the forest fires in Sweden 2018. Nat. Hazards Earth Syst. Sci. Discuss. [preprint], https://doi.org/10.5194/nhess-2019-206, in review, 2019

Krishnakumar S, Balakrishnan N, Muthukrishnan R, Kumar SR (2013) Myth and mystery of soil mycorrhiza: a review. Afr J Agric Res 8:4706-4717

Krokene P, Solheim H (1997) Fungal associates of five bark beetle species colonizing Norway spruce. Can J for Res 26(12):2115-2122. https://doi.org/10.1139/x26-240

Kubiak K, Żółciak A, Damszel M, Lech P, Sierota Z (2017) Armillaria pathogenesis under climate changes. Forests 8:100. https://doi.org/10.3390/f8040100

Kujawa A, Gierczyk B, Kozak M, Mleczko P, Ślusarczyk T (2017) Różnorodność wielkoowocnikowych grzybów agarykoidalnych, boletoidalnych i hypogeicznych Puszczy Białowieskiej - założenia projektu i wstępne wyniki [Diversity of agaricoid, boletoid and hypogeous macrofungi in the Białowieża Forest project concept and preliminary results]. Fragm Florist Geobot Pol 24(1):119-131

Kunca A, Leontovyč R (2013a) Laboratory experiments with growth potential of Cenangium ferruginosum tested on natural nutrition soils. Lesnícky časopis - For J 59(1):44-49

Kunca A, Leontovyč R (2013b) Pine's dieback caused by Cenangium ferruginosum Fr. in Slovakia in 2012. Folia Oecol 40(2):220-224

Kusari S, Verma VC, Lamshoeft M, Spiteller M (2012) An endophytic fungus from Azadirachta indica A. Juss. that produces azadirachtin. World J Microbiol Biotechnol 28:1287-1294. https://doi.org/10.1007/s11274-011-0876-2

Lacey L (ed) (2017) Microbial control of insect and mite pests: from theory to practice. Academic Press, Cambridge

Laganiere J, Angers DA, Pare D (2010) Carbon accumulation in agricultural soils after afforestation: a meta-analysis. Glob Change Biol 16(1):439-453. https://doi.org/10.1111/j.13652486.2009.01930.x

Lamhamedi MS, Bernier PY, Fortin JA (1992) Hydraulic conductance and soil water potential at the soil root interface of Pinus pinaster seedlings inoculated with different dikaryons of Pisolithus sp. Tree Physiol 10(3):231-244. https://doi.org/10.1093/ treephys/10.3.231

Landolt M, Stroheker S, Queloz V, Gall A, Sieber TN (2020) Does water availability influence the abundance of species of the Phialocephala fortinii s. 1. - Acephala applanata complex (PAC) in roots of pubescent oak (Quercus pubescens) and Scots pine (Pinus sylvestris)? Fungal Ecol. https://doi.org/10. 1016/j.funeco.2019.100904

Lenton R, Muller M (2012) Integrated water resources management in practice: better water management for development. Routledge, London, p 248

Lheto T, Zwiazek JJ (2011) Ectomycorrhizas and water relations of trees: a review. Mycorrhiza 21(2):71-90. https://doi.org/10.1007/ s00572-010-0348-9
Liang M, Liu X, Etienne RS, Huang F, Wang Y, Yu S (2015) Arbuscular mycorrhizal fungi counteract the Janzen-Connell effect of soil pathogens. Ecology 96:562-574. https://doi.org/10.1890/ 14-0871.1

Liese R, Leuschner C, Meier IC (2019) The effect of drought and season on root life span in temperate arbuscular mycorrhizal and ectomycorrhizal tree species. J Ecol 107(5):2226-2239. https:// doi.org/10.1111/1365-2745.13181

Lieutier F (2002) Mechanisms of resistance in conifers and bark beetle attack strategies. In: Wagner MR, Clancy KM, Lieutier F, Paine TD (eds) Mechanisms and deployment of resistance in trees to insects. Springer, Dordrecht

Likar M (2018) Dark septate endophytes and mycorrhizal fungi of trees affected by metal pollution. In: Pirttilä A, Frank A (eds) Endophytes of forest trees. Forestry sciences. Springer International Publishing, Berlin, pp 119-137. https://doi.org/10.1007/ 978-3-319-89833-9_6

Lilleskov EA, Fahey TJ, Horton TR, Lovett GM (2002) Belowground ectomycorrhizal fungal community change over a nitrogen deposition gradient in Alaska. Ecology 83(1):104-115

Lindner M, Maroschek M, Netherer S et al (2010) Climate change impacts, adaptive capacity, and vulnerability of European forest ecosystems. For Ecol Manag 259:698-709. https://doi.org/10. 1016/j.foreco.2009.09.023

Liu T, Sheng M, Wang CY, Chen H, Li Z, Tang M (2015) Impact of arbuscular mycorrhizal fungi on the growth, water status, and photosynthesis of hybrid poplar under drought stress and recovery. Photosynthetica 53(2):250-258

Lugtenberg BJJ, Caradus JR, Johnson LJ (2016) Fungal endophytes for sustainable crop production. FEMS Microbiol Ecol 92(12):fiw 194. https://doi.org/10.1093/femsec/fiw 194

Lum MR, Hirsch AM (2002) Roots and their symbiotic microbes: Strategies to obtain nitrogen and phosphorus in a nutrient-limiting environment. J Plant Growth Regul 21(4):368-382. https://doi. org/10.1007/s00344-003-0003-1

Lung-Escarmant B, Guyon D (2003) Temporal and spatial dynamics of primary and secondary infection by Armillaria ostoyae in a Pinus pinaster plantation. Phytopathology 94(2):125-131. https://doi. org/10.1094/PHYTO.2004.94.2.125

Lyr H, Fiedler HJ, Tranquillini W (1992) Physiologie und Ökologie der Gehölze. Gustav Fischer Verlag, Stuttgart

Manion PD (1991) Tree disease concepts. Prentice-Hall, Englewood Cliffs

Marcais B, Breda N (2006) Role of an opportunistic pathogen in the decline of stressed oak trees. J Ecol 94(6):1214-1223. https:// doi.org/10.1111/j.1365-2745.2006.01173.x

Mariotte P, Canarini A, Dijkstra FA (2017) Stoichiometric N: P flexibility and mycorrhizal symbiosis favour plant resistance against drought. J Ecol 150(4):958-967. https://doi.org/10.1111/13652745.12731

Marschner H, Dell B (1994) Nutrient uptake in mycorrhizal symbiosis. Plant Soil 159:89-102

Masante D, Vogt J, Cammalleri C, Spinoni J, Barbosa P (2018) Drought in Central-Northern Europe - September 2018 EDO Analytical Report Copernicus EMS - European Drought Observatory (EDO). https://edo.jrc.ec.europa.eu/documents/news/ EDODroughtNews201809_Central_North_Europe.pdf

Masante D, Barbosa P, Magni D (2019) Drought in Europe - August 2019 EDO Analytical Report Copernicus EMS - European Drought Observatory (EDO). https://edo.jrc.ec.europa.eu/docum ents/news/EDODroughtNews201908_Europe.pdf. Accessed 20 Feb 2020

Mezei P, Jakuš R, Pennerstorfer J, Havašová M et al (2017) Storms, temperature maxima and the Eurasian spruce bark beetle Ips typographus - an infernal trio in Norway spruce forests of the 
Central European high Tatra Mountains. Agric for Meteorol 242:85-95. https://doi.org/10.1016/jagrformet.2017.04.004

Milligan G, Cox ES, Alday JG, Santana VM, Mcallister HA, Pakeman RJ, Le Duc MG, Marrs RH (2016) The effectiveness of old and new strategies for the long-term control of Pteridium aquilinum, an 8-year test. Weed Res. https://doi.org/10.1111/wre.12203

Miścicki S (2016) Zmiany drzewostanów Białowieskiego Parku Narodowego w okresie 2000-2015 [Changes in the stands of the Białowieża National Park from 2000 to 2015] Leśne Prace Badawcze/For Res Pap 77(4):371-379. https://doi.org/10.1515/ frp-2016-0038

Morgado LN, Semenova TA, Welker JM, Welker MD, Smets E, Geml J (2015) Summer temperature increase has distinct effects on the ectomycorrhizal fungal communities of moist tussock and dry tundra in Arctic Alasca. Glob Change Biol 21(2):959-972. https://doi.org/10.1111/gcb.12716

Morgado LN, Semenova TA, Welker JM, Welker MD, Smets E, Geml J (2016) Long-term increase in snow depth leads to compositional changes in arctic ectomycorrhizal fungal communities. Glob Change Biol 22(9):3080-3096. https://doi.org/10.1111/ gcb. 13294

Morte A, Díaz G, Rodríguez P, Alarcón JJ, Sánchez-Blanco MJ (2001) Growth and water relations in mycorrhizal and non-mycorrhizal Pinus halepensis plants in response to drought. Biol Plant. https://doi.org/10.1023/A:1010207610974

Mousa WK, Raizada MN (2013) The diversity of anti-microbial secondary metabolites produced by fungal endophytes: an interdisciplinary perspective. Front Microbiol 4:65. https://doi.org/10. 3389/fmicb.2013.00065

Musierowicz A, Król H (1962) Współzależność między pojemnością wodną polową i kapilarną gleb [Correlation between field water capacity and capillary capacity] Rocz Gleb 12:161-177

Nedelin T (2014) Ectomycorrhiza - nature and significance for functioning of forest ecosystems. For Ideas 20(1):3-29

Netherer S, Panassiti B, Pennerstorfer J, Matthews B (2019) Acute drought is an important driver of bark beetle infestation in Austrian Norway spruce stands. Front for Glob Change 2:39. https:// doi.org/10.3389/ffgc.2019.00039

Ouden J. den (2000) The role of bracken (Pteridium aquilinum) in forest dynamics. Thesis Wageningen University.

Ouledali S, Ennajeh M, Zrig A et al (2018) Estimating the contribution of arbuscular mycorrhizal fungi to drought tolerance of potted olive trees (Olea europaea). Acta Physiol Plant 40:81. https:// doi.org/10.1007/s11738-018-2656-1

Pandey P, Sinha R, Mysore KS, Senthil-Kumar M (2015) Impact of concurrent drought stress and pathogen infection on plants. In: Mahalingam R (ed) Combined stresses in plants. Springer International Publishing, Cham, pp 203-222. https://doi.org/10.1007/ 978-3-319-07899-1_10

Panka S (2012) Gatunki drzew obcego pochodzenia na leśnych powierzchniach doświadczalnych Brandenburgii [Alien tree species in experimental forest plots in Brandenburg]. Rocz Pol Tow Dendrol 60:21-42

Parke EL, Linderman RG, Black CH (1983) The role of ectomycorrhizas in drought tolerance of Douglas-fir seedlings. New Phtol 95(1):83-95. https://doi.org/10.1111/j.1469-8137.1983.tb034 71. $\mathrm{x}$

Parmesan C (2006) Ecological and evolutionary responses to recent climate change. Annu Rev Ecol Evol Syst 37:637-669. https:// doi.org/10.1146/annurev.ecolsys.37.091305.110100

Parniske M (2008) Arbuscular mycorrhiza: the mother of plant root endosymbioses. Nat Rev Microbiol 6:763-775

Paszkowski U (2006) A journey through signaling in arbuscular mycorrhizal symbioses Tansley review. New Phytol 172:35-46

Pautasso M, Aas G, Queloz V, Holdenrieder O (2013) European ash (Fraxinus excelsior) dieback-a conservation biology challenge.
Biol Conserv 158:37-49. https://doi.org/10.1016/j.biocon.2012. 08.026

Pavithra D, Yapa N (2018) Arbuscular mycorrhizal fungi inoculation enhances drought stress tolerance of plants. Ground Water Sust Dev 7:490-494. https://doi.org/10.1016/j.gsd.2018.03.005

Peay KG, Russo SR, McGuire KL, Lim Z, Chan JP, Tan S, Davies SJ (2015) Lack of host specificity leads to independent assortment of dipterocarps and ectomycorrhizal fungi across a soil fertility gradient. Ecol Lett 18(8):807-816. https://doi.org/10.1111/ele. 12459

Peterken GF (1999) Applying natural forestry concepts in an intensively managed landscape. Glob Ecol Biogeogr 8(5):321-328

Pickles BJ, Egger KN, Massicotte HB, Green DS (2012) Ectomycorrhizas and climate change. Fungal Ecol 5(1):73-84. https://doi. org/10.1016/j.funeco.2011.08.009

Pilosof S, Porter MA, Pascual M, Kéfi S (2017) The multilayer nature of ecological networks. Nat Ecol Evol 1(4):0101. https://doi.org/ 10.1038/s41559-017-0101

Piri T (2003) Silvicultural control of Heterobasidion root rot in Norway spruce forests in southern Finland: Regeneration and vitality fertilization of infected stands Academic Dissertation Faculty of Agriculture and Forestry of the University of Helsinki. The Finnish Forest Research Institute, Research Papers 898: pp. 1-64

Plagnat F (1950) The Fir Mistletoe, Viscum album f. sp. abietis. Annales De L'école Nationale Des Eaux Et Forêts, Nancy $12: 155-231$

Plamboeck AH, Dawson TE, Egerton-Warburton LM, North M, Bruns TD, Querejeta JI (2007) Water transfer via ectomycorrhizal fungal hyphae to conifer seedlings. Mycorrhiza 17(5):439-447. https://doi.org/10.1007/s00572-007-0119-4

Prieto I, Roldán A, Huygans D, Alguacil MD, Navarro-Cano JA, Querejeta JI (2016) Species-specific roles of ectomycorrhizal fungi in facilitating interplant transfer of hydraulically redistributed water between Pinus halepensis saplings and seedlings. Plant Soil 406:15-27. https://doi.org/10.1007/ s11104-016-2860-y

Pritsch K, Garbaye J (2011) Enzyme secretion by ECM fungi and exploitation of mineral nutrients from soil organic matter. Ann for Sci 68:25-32. https://doi.org/10.1007/s13595-010-0004-8

Przybył K (2002) Fungi associated with necrotic apical parts of Fraxinus excelsior shoots. Forest Pathol 32(6):387-394. https://doi. org/10.1046/j.1439-0329.2002.00301.x

Raitio H (2000) Weather conditions during 1980-1995 and tree damage directly attributable to weather. In: Mälkönen E (ed) Forest condition in a changing environment. Forestry sciences 65. Springer, Berlin, pp 41-48. https://doi.org/10.1007/ 978-94-015-9373-1_5

Rana KL, Kour D, Sheikh I, Dhiman A, Yadav N, Yadav AN, Rastegari AA, Singh K, Saxena AK (2019) Endophytic fungi: biodiversity, ecological significance, and potential industrial applications. In: Yadav A, Mishra S, Singh S, Gupta A (eds) Recent advancement in white biotechnology through fungi. Fungal biology. Springer, Cham, pp 1-62

Read DJ, Boyd R (1986) Water relations of mycorrhizal fungi and their host plants. In: Ayres P, Boddy L (eds) Water, fungi, and plants. Cambridge University Press, Cambridge, pp 287-303

Rebetez M, Mayer H, Dupont O, Schindler D, Gartner K, Kropp JP, Menzel A (2006) Heat and drought 2003 in Europe: a climate synthesis. Ann for Sci 63:569-577. https://doi.org/10.1051/ forest:2006043

Rodriguez R, Redman R (2008) More than 400 million years of evolution and plants still can't make it on their own, plant stress tolerance and habitat expansion via fungal symbiosis. J Exp Bot 59(5):1109-1114. https://doi.org/10.1093/jxb/erm342

Rodriguez RJ, Henson J, Van Volkenburgh E, Hoy M, Wright L, Beckwith F et al (2008) Stress tolerance in plants via 
habitat-adapted symbiosis. ISME J 2(4):404-416. https://doi. org/10.1038/ismej.2007.106

Rodriguez RJ, White JF, Arnold AE, Redman RS (2009) Fungal endophytes: diversity and functional roles. New Phytol 182(2):314330. https://doi.org/10.1111/j.1469-8137.2009.02773.x

Rousseau JVD, Reid CCP, English RJ (1992) Relationship between biomass of the mycorrhizal fungus Pisolithus tinctorius and phosphorus uptake in loblolly pine seedlings. Soil Biol Biochem 24(2):183-184. https://doi.org/10.1016/0038-0717(92)90276-4

Ryu M, Mishra RCH, Jeon J, Lee SK, Bae H (2018) Drought-induced susceptibility for Cenangium ferruginosum leads to progression of Cenangium dieback disease in Pinus koraiensis. Sci Rep 8(1):16368. https://doi.org/10.1038/s41598-018-34318-6

Saarsalmi A, Smolander A, Moilanen M, Kukkola M (2014) Wood ash in boreal, low-productive pine stands on upland and peatland sites: long-term effects on stand growth and soil properties. For Ecol Manag 327:86-95. https://doi.org/10.1016/j.foreco.2014. 04.031

Saikkonen K, Young CA, Helander M, Schardl CL (2016) Endophytic Epichloë species and their grass hosts: from evolution to applications. Plant Mol Biol. https://doi.org/10.1007/ s11103-015-0399-6

Salam EA, Alatar A, El-Sheikh MA (2017) Inoculation with arbuscular mycorrhizal fungi alleviates harmful effects of drought stress on damask rose. Saudi J Biol Sci 25(8):1772-1780. https://doi.org/ 10.1016/j.sjbs.2017.10.015

Sanaullah M, Chabbi A, Rumpel C, Kuzyakov Y (2012) Carbon allocation in grassland communities under drought stress followed by ${ }^{14} \mathrm{C}$ pulse labeling. Soil Biol Biochem 55:132-139. https://doi. org/10.1016/j.soilbio.2012.06.004

Schmidt O (2006) Wood and tree fungi: biology, damage, protection, and use. Springer-Verlag, Germany

Schoeneweiss DF (1981) Infectious diseases of trees associated with water and freezing stress. J Arbor 7(1):13-18

Schubert A, Marzachi C, Mazzitelli M, Cravero MC, BonfanteFasolo P (1987) Development of total and viable extraradical mycelium in the vesicular-arbuscular mycorrhizal fungus Glomus clarum Nicol. \& Schenck. New Phytol 107:183-190

Schuldt B, Buras A, Arend M et al (2020) A first assessment of the impact of the extreme 2018 summer drought on Central European forests. Basic Appl Ecol 45:85-103. https://doi.org/10. 1016/j.baae.2020.04.003

Schulz B, Boyle C (2005) The endophytic continuum. Mycoll Res 109(6):661-686. https://doi.org/10.1017/S095375620500273X

Schulz B, Boyle C, Draeger S, Römmert A, Krohn K (2002) Endophytic fungi: a source of novel biologically active secondary metabolites. Mycol Res 106(9):996-1004. https://doi.org/10. 1017/S0953756202006342

Shahin O, Paul NM-S, Rambal S, Joffre R, Richard F (2013) Ectomycorrhizal fungal diversity in Quercus ilex Mediterranean woodlands: variation among sites and over soil depth profiles in hyphal exploration types, species richness and community composition. Symbiosis 61(1):1-12. https://doi.org/10.1007/ s13199-013-0252-0

Sieber TN (2007) Endophytic fungi in forest trees: are they mutualists? Fungal Biol Rev 21(2-3):75-89. https://doi.org/10.1016/j. fbr.2007.05.004

Sierota Z (2013) Heterobasidion root rot in forests on former agricultural lands in Poland: scale of threat and prevention. Sci Res Essays 8(47):2298-2305

Sierota Z, Grodzki W (2020) Picea abies-Armillaria-Ips: a strategy or coincidence? Forests 11:1023. https://doi.org/10.3390/f11091023

Sierota Z, Kolk A, Ślusarski S (1998) Przyczyny i przebieg zjawiska zamierania pędów sosny zwyczajnej na terenie północnozachodniej części Polski w latach 1995-1997 [Causes and course of the phenomenon of dieback of Scots pine in the north-west of
Poland in 1995-1997]. Prace Instytutu Badawczego Leśnictwa, Ser B 34:75-93

Sierota Z, Grodzki W, Szczepkowski A (2019) Abiotic and biotic disturbances affecting forest health in poland over the past 30 years: impacts of climate and forest management. Forests 10(1):75. https://doi.org/10.3390/f10010075

Sierota Z (2011) Gdy las choruje [When the forest is ill] Centrum Informacyjne Lasów Państwowych, Warszawa

Simard SW (2009) Mycorrhizal networks and complex systems: contributions of soil ecology science to managing climate change effects in forested ecosystems. Can Soil Sci 89:369-382. https:// doi.org/10.4141/cjss08078

Simard SW, Jones MD, Durall DM (2003) Carbon and nutrient fluxes within and between mycorrhizal plants. In: Van der Heijden MGA, Sanders IR (eds) Mycorrhizal ecology ecological studies. Analysis and synthesis. Springer, Berlin, pp 33-74. https:// doi.org/10.1007/978-3-540-38364-2_2

Simard S (2016) How Trees Talk To Each Other. http://www.ted.com/ talks/suzanne_simard_how_trees_talk_to_each_other. [Accessed 20 Feb 2020]

Skrypnik L, Maslennikov P, Feduraev P, Pungin A, Belov N (2020) Ecological and landscape factors affecting the spread of European mistletoe (Viscum album L) in urban areas (A Case Study of the Kaliningrad City, Russia). Plants 9(3):394. https://doi.org/ $10.3390 /$ plants 9030394

Škvarenina J, Vida T (2009) Metodologické aspekty hodnotenie sucha a rizika lesných požiarov $\mathrm{v}$ meniacich sa podmienkach klímy na Slovensku [Methodology aspects of drought and forest fire danger assessment in changing conditions of climate in the Slovak republic]. Acta Facultatis Forestalis Zvolen 51(3):17-33

Smal H, Olszewska M (2008) The effect of afforestation with Scots pine (Pinus silvestris L) of sandy post-arable soils on their selected properties II reaction, carbon, nitrogen, and phosphorus. Plant Soil 305(1-2):171-187. https://doi.org/10.1007/ s11104-008-9538-Z

Smith SE, Read DJ (2008) Mycorrhizal symbiosis. Academic Press, Cambridge. https://doi.org/10.1016/ B978-0-12-370526-6X5001-6

Socha J, Orzeł S (2013) Dynamiczne krzywe bonitacyjne dla sosny zwyczajnej (Pinus sylvestris L) z południowej Polski [Dynamic site index curves for Scots pine (Pinus sylvestris L) in southern Poland]. Sylwan 157(1):26-38

Solon J, Borzyszkowski J, Bidłasik M, Richling A, Badora K, Balon J, BrzezińskaWójcik T, Dobrowolski R, Grzegorczyk I, Jodłowski M, Kistowski M, Kot R, Krąż P, Lechnio J, Macias A, Majchrowska A, Malinowska E, Migoń P, Myga-Piątek U, Nita J, Papińska E, Rodzik J, Superson J, Terpiłowski S, Turczyński M, Ziaja W (2018) Mezoregiony fizycznogeograficzne Polski - weryfikacja i uszczegółowienie granic na podstawie współczesnych danych przestrzennych / Physico-geographical mesoregions of Poland: Verification and adjustment of boundaries on the basis of contemporary spatial data; in Polish/. Geographia Polonica 91 (2)

Soloviy IP (2000) Afforestation in Ukraine - Potential and Restrictions. In: Weber N NEWFOR - New Forests for Europe: Afforestation at the Turn of the Century. EFI Proc. No.35 Joensuu, Finland

Song RQ, Ju HB, Qi JY, Zhou BR (2007) Effect of ectomycorrhizal fungi on seedling growth of mongol scotch pine. J Fungal Res 5(3):142-145

Spinoni J, Arias Muñoz C, Masante D, McCormick N, Vogt JV, Barbosa P (2018) European Drought Observatory User Meeting 2018, European Commission, Ispra (VA), Italy, JRC114677

Staniaszek J, Socha J (2015) Długookresowe trendy w dynamice wzrostu wysokości sosny zwyczajnej w Puszczy Niepołomickiej [Long-term trends in height growth dynamics of Scots pine in Niepołomice Forest]. Acta Agr Silv Ser Silv 53:49-60 
Stenström E (1991) The effects of flooding on the formation of ectomycorrhizae in Pinus sylvestris seedlings. Plant Soil 131:247-250. https://doi.org/10.1007/BF00009455

Stocker TF, Qin D, Plattner G-K, Tignor M, Allen SK, Boschung J, Nauels A, Xia Y, Bex B, Midgley BM (2013) Climate change 2013: The Physical Science Basis Contribution of Working Group I to the Fifth Assessment. Report of the Intergovernmental Panel on Climate Change. Cambridge University Press, Cambridge

Stroheker S, Dubach V, Queloz V, Sieber TN (2018) Resilience of Phialocephala fortinii s.1.-Acephala applanate communities-Effects of disturbance and strain introduction. Fungal Ecol 31:19-28

Sutinen M-L, Mäkitalo K, Sutinen R (1996) Freezing dehydration damages roots of containerized Scots pine (Pinus sylvestris) seedlings overwintering under subarctic conditions. Can $\mathrm{J}$ for Res 26(9):1602-1609. https://doi.org/10.1139/x26-180

Szabla K, Pabian R (2009) Szkółkarstwo kontenerowe, nowe technologie i techniki w szkółkarstwie leśnym. Warszawa: Centrum Informacyjne Lasów Państwowych (in Polish)

Szczepkowski A, Gierczyk B, Ślusarczyk T, Kujawa A (2021) Contribution to the knowledge of fungi of the Kampinos National Park (central Poland): part 4 - with particular emphasis on the species occurring on windthrown trees Acta Mycol 56(1) (in press)

Szmidla H, Tkaczyk M, Plewa R, Tarwacki G, Sierota Z (2019) Impact of common mistletoe (Viscum album $\mathrm{L}$ ) on Scots pine forests a call for action. Forests 10:847. https://doi.org/10.3390/f1010 0847

Taiz L, Zeiger E (2006) Plant physiology. Sinauer Associates Inc, Sunderland

Takemoto S, Nakamura HE, Imamura Y, Shimane T (2010) Schizophyllum commune as a ubiquitous plant parasite. Jpn Int Res Cent Agric Sci 44(4):357-364. https://doi.org/10.6090/jarq.44.35

Taylor AFS, Alexander I (2005) The ectomycorrhizal symbiosis: life in the real world. Mycologist 19(3):102-112. https://doi.org/10. 1017/S0269-915X(05)00303-4

Terhonen E, Kovalchuk A, Zarsav A, Asiegbu FO (2018) Biocontrol potential of forest tree endophytes. In: Pirttilä AM, Frank AC (eds) Endophytes of forest trees: biology and applications, vol 2. Springer International Publishing AG, Basel, pp 283-318. https://doi.org/10.1007/978-3-319-89833-9_13

Terhonen E, Langer GJ, Bußkamp J, Răscuțoi DR, Blumenstein K (2019) Low water availability increases necrosis in Picea abies after artificial inoculation with fungal root rot pathogens Heterobasidion parviporum and Heterobasidion annosum. Forests 10:55. https://doi.org/10.3390/f10010055

Teste FP, Jones MD, Dickie IA (2020) Dual-mycorrhizal plants: their ecology and relevance. New Phytol 225(5):1835-1851. https:// doi.org/10.1111/nph.16190

Thomson BD, Grove TS, Malajczuk N, Hardy GES (1994) The effectiveness of ectomycorrhizal fungi increasing the growth of Eucalyptus globulus labill in relation to root colonization and hyphal development in soil. New Phytol 126(3):517-524. https://doi.org/ 10.1111/j.1469-8137.1994.tb04250.x

Thuiller W, Richardson DM, Midgley GF (2008) Will climate change promote alien plant invasions? In: Nentwig W (ed) Biological invasions, ecological studies (Analysis and Synthesis). Springer, Berlin, pp 197-211. https://doi.org/10.1007/978-3-540-369202_12

Tkaczyk M, Sikora K (2020) First report of the occurrence of Sphaeropsis visci on Mistletoe (Viscum album L.) in Poland. Balt for 26(1):2-4. https://doi.org/10.46490/BF461

Tyburski Ł, Zaniewski PT, Bolibok L, Piątkowski M, Szczepkowski A (2019) Scots pine Pinus sylvestris mortality after surface fire in oligotrophic pine forest Peucedano-Pinetum in Kampinos
National Park. Folia for Pol Ser A 61(1):51-57. https://doi.org/ 10.2478/ffp-2019-0005

Unestam T, Sun YP (1995) Extramatrical structures of hydrophobic and hydrophilic ectomycorrhizal fungi. Mycorrhiza 5:301-311

Unterseher M (2011) Diversity of fungal endophytes in temperate forest trees. In: Pirttilä AM, Frank AC (eds) Endophytes of forest trees: biology and applications. Forestry sciences. Springer Sciences + Business Media, Berlin, pp 31-46. https://doi.org/10.1007/ 978-94-007-1599-8-2

Van der Heijden MG, Martin FM, Sellose MA, Sanders IR (2015) Mycorrhizal ecology and evolution: the past, the present, and the future. New Phytol 205(4):1406-1423. https://doi.org/10. 1111/nph.13288

Van der Linde S, Suz LM, Orme CDL et al (2018) Environment and host as large-scale controls of ectomycorrhizal fungi. Nature 558(7709):243-248. https://doi.org/10.1038/s41586-018-0189-9

Vega FE, Blackwell M (eds) (2005) Insect-Fungal associations: ecol evol. Oxford University Press, New York

Venäläinen A, Lehtonen I, Laapas M, Ruosteenoja K, Tikkanen O-P, Viiri H, Ikonen V-P, Peltola H (2020) Climate change induces multiple risks to boreal forests and forestry in Finland: a literature review. Glob Change Biol 26(8):4178-4196. https://doi.org/ $10.1111 /$ gcb. 15183

Verma SK, jr White JF (2019) Seed endophytes: biology and biotechnology. Springer International Publishing AG, Basel

Vitali V, Forrester DI, Bauhus J (2018) Know your neighbours: drought response of Norway spruce, silver fir and douglas fir in mixed forests depends on species identity and diversity of tree neighbourhoods. Ecosystems 21(6):1215-1229. https://doi.org/10. 1007/s10021-017-0214-0

Wang Q, Wu J, Lei T, He B, Wu Z, Liu M, Mo X, Geng G, Li X, Zhou H, Liu D (2014) Temporal-spatial characteristics of severe drought events and their impact on agriculture on a global scale. Quatern Int 349:10-21

Warren JM, Brooks JR, Meinzer FC, Eberhart JL (2008) Hydraulic redistribution of water from Pinus ponderosa trees to seedlings: evidence for an ectomycorrhizal pathway. New Phytol 178(2):382-394. https://doi.org/10.1111/j.1469-8137.2008. 02377.x

Watkinson SC (2016) Mutualistic symbiosis between fungi and autotrophs. In: Watkinson SC, Boddy L, Money NP (eds) The fungi. Academic Press, Cambridge, pp 234-239

Weber G, Claus M (2000) The influence of chemical soil factors on the development of VA mycorrhizas of ash (Fraxinus excelsior L.) and sycamore (Acer pseudoplatanus L.) in pot experiments. J Plant Nutr Soil Sci 163:609-616. https://doi.org/10.1002/15222624(200012)163:6\%3c609:AID-JPLN609\%3e3.0.CO;2-X

Wegehenkel M (2003) Longterm evaluation of land use changes on catchment water balance-a case study from North-East Germany. Phys Chem Earth A/b/c 28(33-36):1281-1290. https:// doi.org/10.1016/j.pce.2003.09.004

Wieder WR, Cleveland CC, Townsend AR (2009) Controls over leaf litter decomposition in wet tropical forests. Ecology 90(12):3333-3341. https://doi.org/10.1890/08-2294.1

Witzell J, Martín JA (2018) Endophytes and forest health. In: Pirttilä AM, Frank AC (eds) Endophytes of forest trees: biology and applications. Forestry sciences. Springer International Publishing AG, Basel, pp 261-282. https://doi.org/10.1007/978-3-31989833-9 12

Xu H, Zwiazek JJ (2020) Fungal aquaporins in ectomycorrhizal root water transport. Front Plant Sci 11:302. https://doi.org/10.3389/ fpls.2020.00302

Yang Y, Tang M, Sulpice R, Chen H, Tian S, Ban Y (2014) Arbuscular mycorrhizal fungi alter fractal dimension characteristics of $R o b$ inia pseudoacacia, L. seedlings through regulating plant growth, leaf water status, photosynthesis, and nutrient concentration 
under drought stress. J Plant Growth Regul 33:612-625. https:// doi.org/10.1007/s00344-013-9410-0

Zajączkowski G, Jabłoński M, Jabłoński T, Kowalska A, Małachowska J, Piwnicki J (2019) Raport o stanie lasów w Polsce 2018 [The state forests in Poland 2018] Centrum Informacyjne Lasów Państwowych, Warszawa

Zajączkowski G, Jabłoński M, Jabłoński T, Szmidla H, Kowalska A, Małachowska J, Piwnicki J (2020) Raport o stanie lasów w Polsce 2019 [The state forests in Poland 2019] Centrum Informacyjne Lasów Państwowych, Warszawa

Zhang Y, Han T, Ming Q, Wu L, Rahman K, Qin L (2012) Alkaloids produced by endophytic fungi: a review. Nat Prod Commun 7(7):963-968

Zhu XC, Song FB, Xu HW (2010) Arbuscular mycorrhizae improve low temperature stress in maize via alterations in host water status and photosynthesis. Plant Soil 331:129-137. https://doi. org/10.1007/s11104-009-0239-Z

Żółciak A (2019) Determination of Pleurotus abieticola ligninolytic activity on Norway spruce wood. Folia for Polon, Ser A - for 61(4):267-277

Zuber D (2004) Biological flora of central Europe: Viscum album L. Flora-Morphol, Distrib, Funct Ecol Plants 199(3):181-203

Publisher's Note Springer Nature remains neutral with regard to jurisdictional claims in published maps and institutional affiliations. 